\title{
Spiro Iminosugars: Structural Diversity and Synthetic Strategies
}

\author{
Damien Hazelard ${ }^{a}$, Raphaël Hensienne ${ }^{a}$, Jean-Bernard Behr ${ }^{b}$, and Philippe \\ Compain $^{\mathrm{a}}$ \\ a) Laboratoire d'Innovation Moléculaire et Applications \\ Univ. de Strasbourg | Univ. de Haute-Alsace | CNRS | LIMA (UMR 7042) \\ Equipe de Synthèse Organique et Molécules Bioactives (SYBIO), ECPM \\ 25 Rue Becquerel, 67000 Strasbourg, France \\ b) Institut de Chimie Moléculaire de Reims \\ Univ. Reims Champagne Ardenne | CNRS (UMR 7312) \\ Méthodologie en Synthèse Organique (MSO) \\ Moulin de la Housse, 51687 Reims Cedex 2, France. \\ e-mails: philippe.compain@unistra.fr;jb.behr@univ-reims.fr
}

\begin{abstract}
From their discovery in the late 1960's, iminosugars have undergone an expansion from an area of science limited to a few researchers to a field that now attracts the interest of members of the whole synthetic organic chemistry community. Indeed, many tasks concern structural modifications of standard iminosugars in order to improve their biological and pharmacological properties. In this way, the introduction of an adjoining spiro cycle afforded unprecedented polyhydroxyazaspiranes, the structures and syntheses of which are presented in this chapter. Special attention is paid to the key steps involved in the generation of the pivotal quaternary spiro-atom.
\end{abstract}

Keywords iminosugars, spiro compounds, conformational constraint, glycochemistry, glycosidase inhibitors, glycomimetics

\section{Contents}

1 Introduction

2 Cyclitol-based azaspiranes

3 Carbohydrate-based azaspiranes

3.1 Systems with a nitrogen atom at $\alpha$-position to the spirocyclic center 3.2 Systems with a nitrogen atom at $\beta$-position to the spirocyclic center 4 Iminosugars spiro-linked with carba, oxa and azacyles

4.1 Iminosugar-carbacycle spiro systems 
4.2 Iminosugar-oxacycle spiro systems

4.3 Iminosugar-azacycle spiro systems

5 Conclusion and outlook

References

\section{Introduction}

Azaspirocycles represent structural motifs found in a diversity of natural products and biologically active compounds including alkaloids, such as the neurotoxin histrionicotoxins, or spirocyclic nucleosides related to hydantocidin [1]. The list includes also stemonamine [1e], nankakurine A [1f], halichlorine and cephalotaxine [1]. Inspired by Nature, chemists have recently designed original glycomimetics based on spiranic frameworks. In view of the biological importance of carbohydrate mimics with nitrogen atom replacing the ring oxygen, increasing efforts are directed toward the synthesis of "spiro iminosugars". Historically known as potent glycosidase inhibitors, iminosugars have been shown to inhibit an ever-growing number of therapeutically relevant carbohydrateprocessing enzymes such as glycogen phosphorylases, and most recently also, enzymes that act on non-sugar-substrates [2-8]. Since the discovery of their potential as anti-diabetic agents in the 70's, the interest of chemists and clinical researchers for iminosugars has been steadily strengthened by important breakthroughs. The list includes the development of the pharmacological chaperone concept that culminated in 2016 with the approval of Galafold ${ }^{\mathrm{TM}}$ as the first oral drug for the treatment of Fabry disease [9] or the discovery of large multivalent effects in glycosidase inhibition in the late 2000's [10-12] (Fig. 1). In this review, a spiro iminosugar is defined as a glycomimetic based on a polyhydroxylated spiroazacycle. Such structures combine the advantages of classical iminosugars and of spirocycles. The ability of endocyclic amines to become protonated at physiological $\mathrm{pH}$ may induce effective biological activity by mimicking the structure of the enzymatic oxocarbenium ion-like transition state and/or by promoting strong electrostatic interactions with carboxylate residues in the enzyme active site $[2,13]$. The introduction of a spiranic center is expected to provide conformational rigidity and give access to a diversity of conformations other than the traditional chair or boat of six-membered rings. The original distributions of hydroxyl groups thus obtained are thought to be of likely significance for receptor recognition purposes. Constraining a given structure in orientations that fit the enzymatic active site or binding pocket of the biological target is a strategy widely used in drug discovery [14,15]. Within the context of glycomimetic-based inhibitors/ligands, holding hydroxyl groups in precisely defined arrangements may be a promising tool to gain specificity for a particular protein. In addition, this approach allows the exploration of unfrequented regions of chemical and intellectual property spaces. In contrast to fused bicyclic 
iminosugars based on pyrrolizidine or indolizidine skeletons such as castanospermine, swainsonine or australine (Fig. 1) [16], the field of spiro iminosugars has emerged only recently. Although the first description of polyhydroxylated spiroazacycles dates back to almost 50 years [17], increased scientific interest for such structures has emerged only in the early 2000's. This may be explained in part by the synthetic difficulties associated with spiranic structures including the stereocontrolled formation of the stereogenic quaternary spirocyclic center and the functionalization of the newly formed ring system [18].
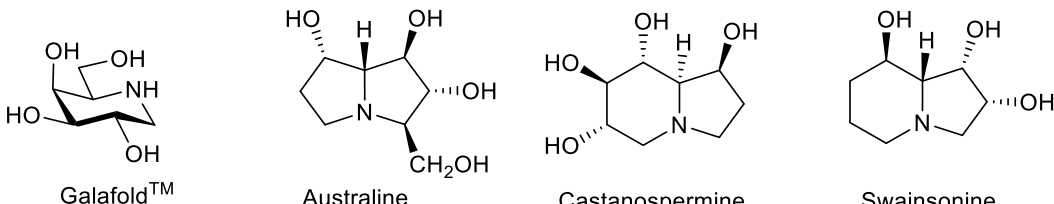

Figure 1 Some representative mono- and bicyclic iminosugars

The purpose of this review is to give an overview of the synthetic strategies designed to address the multiple challenges posed by such structures. Our intent is to focus on the key steps leading to the formation of spiro iminosugars. The review will be organized in three sections: cyclitol-based azaspiranes, glycosidebased azaspiranes and iminosugars spiro-linked with carba-, oxa-, or azacycles (Fig. 2).

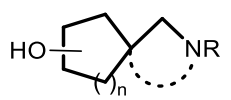<smiles>OCC1(O)C2C[NH+]3CC2C1C3</smiles>

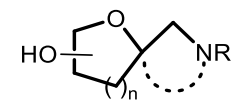

Cyclitol-based azaspiranes

Glycoside-based azaspiranes

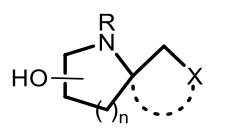<smiles>C1CCC2(C1)CCCC2</smiles>

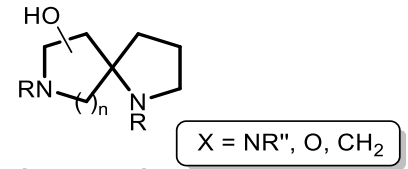

Iminosugars spiro-linked with carba- or heterocycles

Figure 2 Spiro iminosugar structures

We hope that this review will stimulate further research in the area by providing a description of the different types of spiro iminosugars that have been reported so far. Data on their biological activity will be also given whenever such data are available. 


\section{Cyclitol-based Azaspiranes}

A limited number of polyhydroxylated spiroazacycles in which the hydroxyl groups are positioned on a cycloalkane ring has been described in the literature so far. In 2003, Vasella et al. reported the synthesis of spiroaziridines 5 (Scheme 1) [19]. These compounds were designed as mechanistic probes to study the impact of the position of the basic nitrogen atom on the inhibition profile towards a panel of glycosidases. The key alkene intermediate 1 was prepared in three steps from validoxylamine A (Scheme 1). The targeted aziridines were synthesized via the corresponding epoxides $\mathbf{2}$ obtained as a mixture of diastereomers after treatment of 1 with $m$ CPBA ( $86 \%$ yield, d. r. 2.4:1 in favor of $\mathbf{2 b}$ ). Attempts to convert exocyclic alkene 1 into the corresponding $N$-tosyl aziridine using chloramine $\mathrm{T}$ and phenyl(trimethyl)ammonium tribromide led to poor yields. After separation by HPLC, epoxides $\mathbf{2 a}$ and $\mathbf{2 b}$ were treated with $\mathrm{NaN}_{3}$. The resulting ring-opening products $\mathbf{3}$ were converted to the corresponding azido methanesulfonate intermediates which were transformed into aziridines $\mathbf{4}$ by treatment with $\mathrm{LiAlH}_{4}$ in THF. Debenzylation of the spiroaziridines under Birch conditions provided the expected deprotected aziridines 5. Spiroaziridine 5a was found to be particularly unstable and was obtained with a small amount of an unidentified by-product after purification by Sephadex chromatography. Evaluation of azaspiranes $\mathbf{5}$ towards a panel of three glycosidases indicated that $\mathbf{5 b}$ was a weak irreversible inhibitor of the $\beta$-glucosidase from Caldocellum saccharolyticum and a weak reversible inhibitor of the $\beta$-glucosidase from yeast. No inhibition was observed for $\beta$ glucosidase from sweet almonds. Spiroaziridine 5a was a poor inhibitor of the three enzymes. 

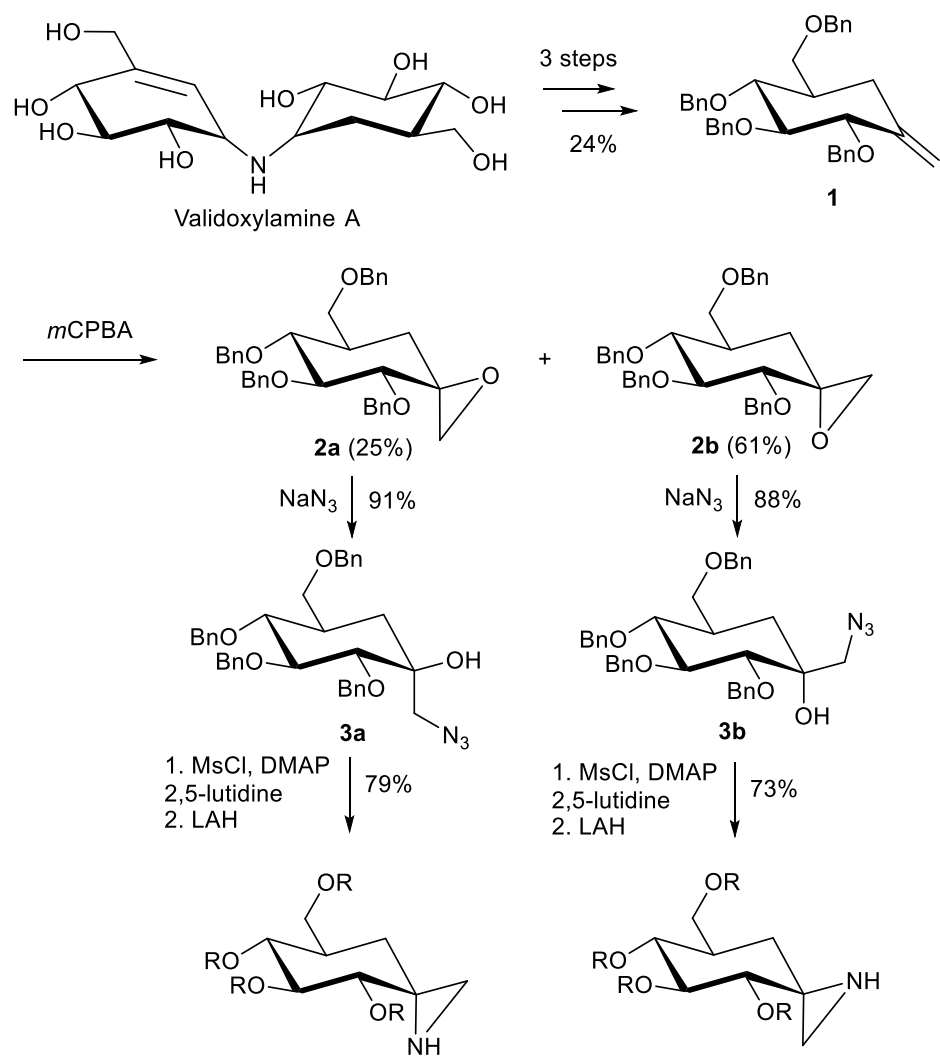

$$
\begin{gathered}
\mathrm{Na}, \mathrm{NH}_{3} \text { liq. } \underset{ }{\longrightarrow} \mathbf{4 a}(\mathrm{R}=\mathrm{Bn}) \\
\text { (see text) }
\end{gathered}
$$

$$
\begin{aligned}
& \mathrm{Na}, \mathrm{NH}_{3} \text { liq. } \\
& \underset{45 \%}{\longrightarrow} \mathbf{4 b}(\mathrm{b} \mathbf{b}(\mathrm{R}=\mathrm{Bn})
\end{aligned}
$$

Scheme 1 Synthesis of spiroaziridines 5

Phosphoribosyl transferase is an attractive target for anti-protozoal chemotherapy. Within the context of the synthesis of carbocyclic phosphoribosyl transferase transition state analogues, Borhani and co-workers reported the synthesis of protected spiroaziridines 7 based on a 5-membered carbasugar [20]. Interestingly, direct copper-catalyzed aziridination of exocylic alkene $\mathbf{6}$ using PhI=NTs provided aziridine $7 \mathbf{a}$ as a single diastereomer, albeit in low yields (Scheme 2). The structure of $7 \mathbf{a}$ was unequivocally confirmed by X-ray analysis of the corresponding ring-opening product obtained after treatment with $\mathrm{Li}_{2} \mathrm{NiBr}_{4}$. The yield of the aziridination reaction could be significantly improved using [(4nitrobenzenesulfonyl)-imino]-phenyliodinane and $\mathrm{Cu}(\mathrm{MeCN})_{4} \mathrm{ClO}_{4}$ as the catalyst. 


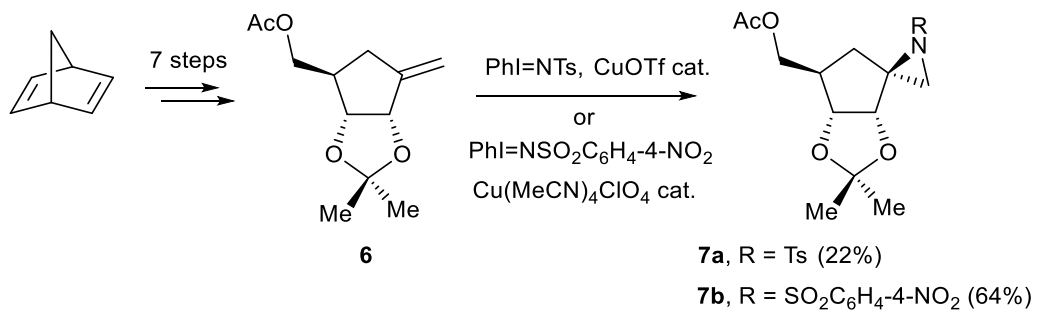

Scheme 2 Synthesis of spiroaziridines 7 via copper-catalyzed aziridination

In 1987, the group of Harrisson reported a model study toward the total synthesis of enantiomerically pure (-)-histrionicotoxins (HTX) from D-mannose (Scheme 3) [21]. Their strategy was to take advantage of the chirality of carbohydrates to access enantiopure natural products and related compounds. The 1azaspiro[5.5] undecane ring system was synthesized by way of successive interand intra-molecular Henry reaction. $\mathrm{KOH}$-catalyzed addition of protected 5-nitropentan-1-ol 14 onto aldehyde 8 obtained in three steps from D-mannose afforded nitro alcohols 9 as a complex mixture of diastereomers. Treatment of the $1-O$-silyl protected furanose 9 with TBAF liberated the anomeric aldehyde group giving rise to an intramolecular Henry reaction. This process afforded the formation of the key quaternary $\mathrm{C}-\mathrm{N}$ bond of the 1-azaspiro[5.5] undecane skeleton. The nitrocyclitols 10 were however obtained as a mixture of diastereomers $(61 \%$ yield). It is noteworthy that, quite remarkably, the related 2-step sequence afforded only a single diastereomer in $70 \%$ yield when nitroethane is used instead of 14 . As a prelude to the formation of the piperidine ring by way of intramolecular $\mathrm{S}_{\mathrm{N}} 2$, the tetrahydropyranyl group was deprotected and the corresponding alcohol was tosylated to afford 11. At this stage, after purification on silica gel, the synthesis was performed on the major diastereomer. Acetylation of diastereomerically pure triol 11 with acetic anhydride in the presence of pyridine provided the nitro derivative 12 which was reduced with aluminum amalgam. Spontaneous ringclosing then afforded the expected polyoxygenated azaspirane $\mathbf{1 3}$ in $72 \%$ yield. 

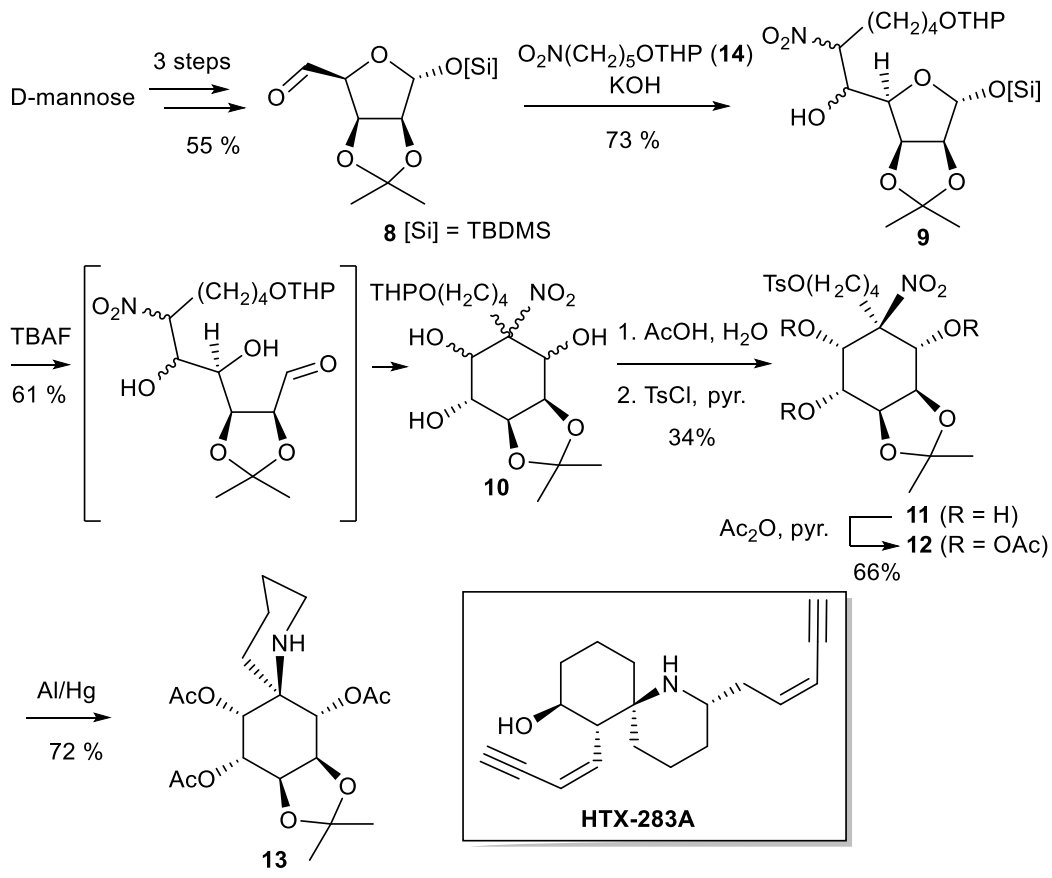

Scheme 3 Synthesis of polyoxygenated 1-azaspiro[5.5] undecane 13 by way of inter and intramolecular Henry reactions.

Other examples of spiro iminosugars with a nitrogen atom directly connected to the quaternary spiro carbon atom were recently described by the group of Compain [22,23]. The key step of the synthesis was the stereocontrolled formation of the pivotal $\mathrm{C}-\mathrm{N}$ bond via nitrene insertion into a $\mathrm{C}-\mathrm{H}$ bond at the spiro carbon atom (Scheme 4). This process which is catalyzed by rhodium(II) complexes occurs with retention of configuration. However, applying such a reaction to polyoxygenated substrates represents a challenge in terms of regioselectivity since insertion is known to be favoured in $\alpha$-ethereal $\mathrm{C}-\mathrm{H}$ bonds. The first part of the synthesis is the preparation of the functionalized square carbasugar 16 [24,25]. This key intermediate was obtained in $67 \%$ yield by way of $\mathrm{SmI}_{2}$-mediated intramolecular coupling reaction of $\gamma, \delta$-unsaturated aldehyde 15 prepared in 6 steps from vitamin $\mathrm{C}$ [24]. To achieve a complete regiocontrol in the pivotal $\mathrm{C}-\mathrm{H}$ amination step, a strategy using a combination of activating and electronwithdrawing groups has to be followed. The mere introduction of a vinylic group was indeed not sufficient to reach high regioselectivity at the spiro carbon atom; electron-withdrawing protecting groups were also required to reduce the electron density at the undesire $\mathrm{C}-\mathrm{H}$ insertion site in $\alpha$-position to the carbamate group. After various attempts, the best $\mathrm{C}-\mathrm{H}$ amination substrate was found to be carbamate $\mathbf{1 7}$ obtained in 4 steps from the cyclization product 16. After having generated the pivotal $\mathrm{C}-\mathrm{N}$ bond of the final targets with retention of configuration 
and high regiocontrol, the final key step of the synthesis entailed the formation of the azacycle by ring-closing metathesis. Despite the additional ring strain generated by the 5-membered ring closure, the expected tricyclic spirocycle derivative 19 was obtained in high yield using $5 \mathrm{~mol} \%$ of Grubbs II catalyst. Unprecedented constrained iminosugars 21 and 23-24 were then obtained in 2 or 3 steps from the common intermediate 19 thus generated (Scheme 4). Preliminary biological evaluations were performed and led to the identification of a new class of correctors of defective F508del-CFTR gating involved in cystic fibrosis (CFTR : Cystic Fibrosis Transmembrane conductance Regulator). The best corrector of the spiranic series, iminosugar 24, displayed a F508del-CFTR activity rescue not significantly different from the $N$-Bu DNJ-induced one [23]. $N$-Bu DNJ - also named miglustat - is a clinical candidate for the treatment of cystic fibrosis.
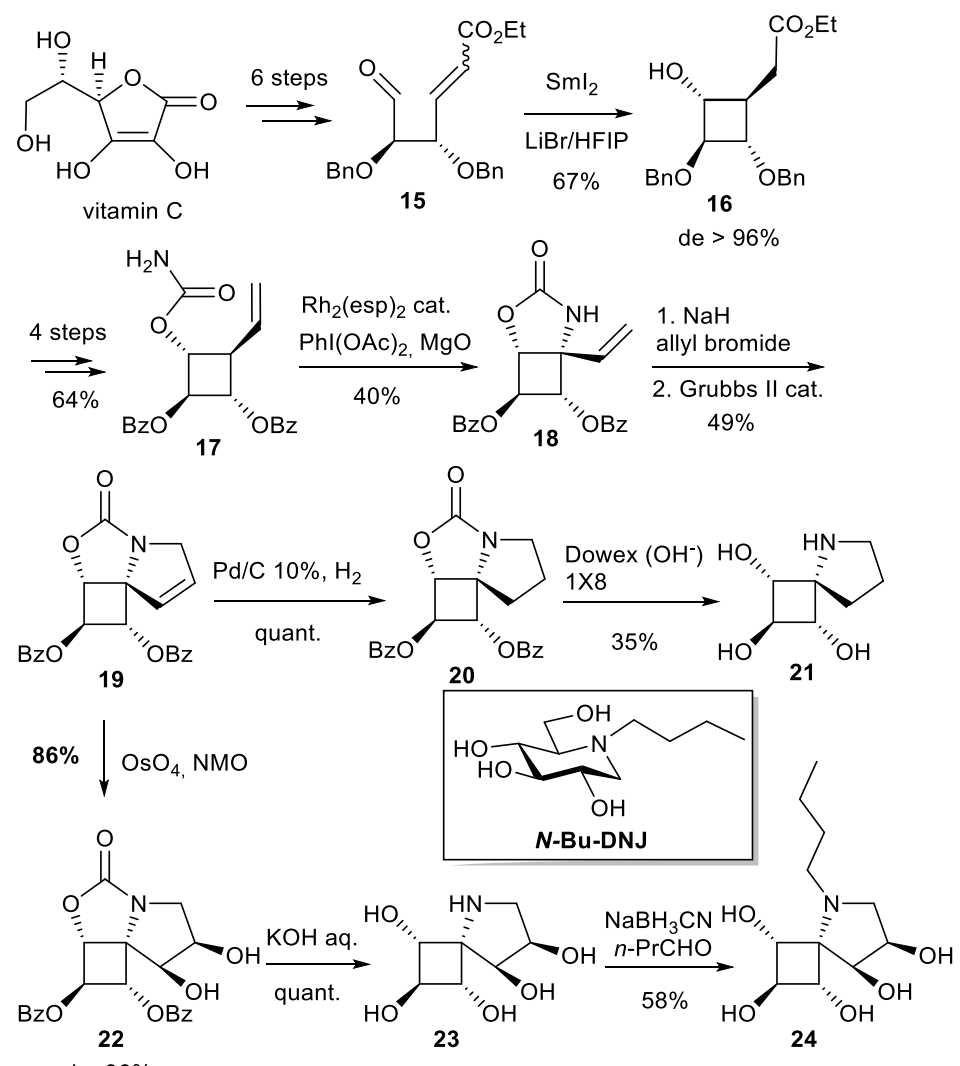

Scheme 4 Synthesis of 4-membered cyclitol-based spiro iminosugars

Cyclitol-based iminosugars where the nitrogen is not directly connected to the quaternary spirocarbon have been described by the group of Miller [26]. The spirocyclic skeleton was efficiently constructed via the dialkylation of 
cyclopentadiene with $N$-protected bis-2-chloroethylamines 25 (Scheme 5). The spiranic dienes $\mathbf{2 6}$ were then engaged in a series of iminonitroso Diels-Alder reactions to yield the corresponding cycloadducts $\mathbf{2 7}$ in good yields. In addition to the stereocontrolled formation of two carbon-heteroatom bonds, one advantage of this cycloaddition process is that the resulting endocyclic alkenes are converted into the corresponding diols $\mathbf{2 8}$ with high diastereoselectivity under Upjohn reaction conditions $\left(\mathrm{OsO}_{4}, \mathrm{~N}\right.$-methyl morpholine- $N$-oxide, NMO). The one-step cleavage of the $\mathrm{N}-\mathrm{O}$ bond and deprotection of the $\mathrm{Cbz}$ group provided the 4amino-8-azaspiro[4.5]decanols 29 in high yields (racemic form).
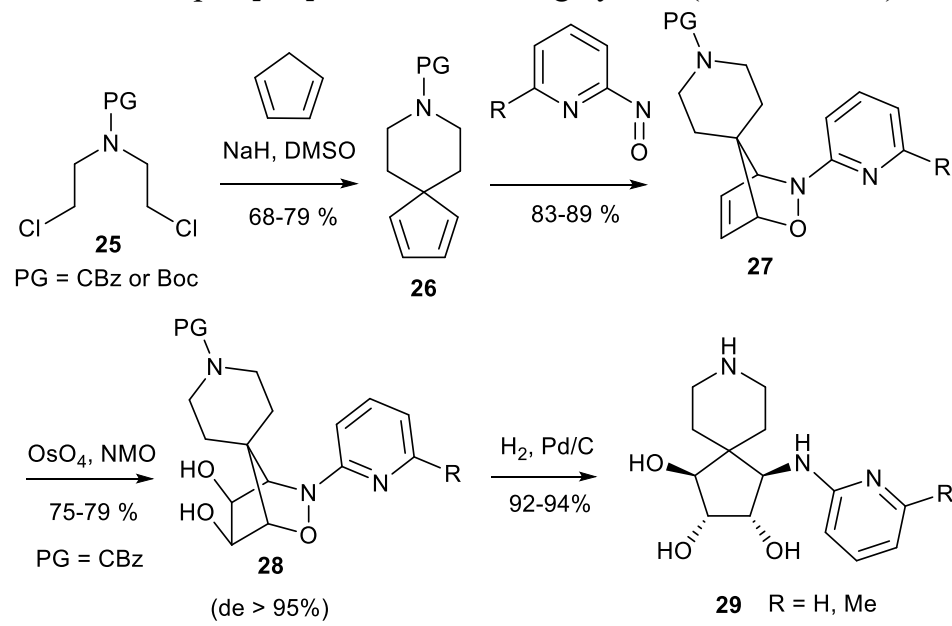

Scheme 5 Synthesis of 4-amino-8-azaspiro[4.5]decanols 29

\section{Carbohydrate-based Azaspiranes}

It is not surprising that several synthetic carbohydrate-based spiroazacycles have been described in the literature. The preparation of such compounds takes indeed advantage of the use of carbohydrates as starting materials. Biologically relevant carbohydrate-based azaspiranes are also found in Nature as shown by the herbicide hydantocidin, a nucleoside having a unique structure with a spiro-annelated hydantoin and ribose [27]. 


\subsection{Systems with a nitrogen atom at $\alpha$-position to the spirocyclic center}

Suarez and co-workers reported the regio- and stereoselective formation of oxa-1azaspirocycles by way of intramolecular hydrogen atom transfer (HAT) (Scheme $6)[28,29]$. This strategy is based on the formation of an electrophilic $N$-radical followed by subsequent abstraction of a hydrogen atom at the pseudo anomeric position. The nucleophilic $C$-radical thus formed is oxidized to an oxonium ion which reacts with the amine group [30]. The authors synthesized several carbohydrate substrates 30 with different ring sizes and protecting groups. Irradiation of compounds 30 in the presence of molecular iodine and $\mathrm{PhI}(\mathrm{OAc})_{2}$ afforded spiroaminals 31 [28,29,1a]. Better yields were obtained for the formation of five membered in comparison to six membered rings. This difference of reactivity could be explained by a more favourable 1,5 HAT through a six membered transition state. Furthermore, the methodology described was compatible with the most common protecting groups in carbohydrate chemistry. However, the introduction of an electron withdrawing protecting group (acetate) at C-2 inhibits the radical abstraction at $\mathrm{C}-1$ and the substrate was recovered unchanged. 


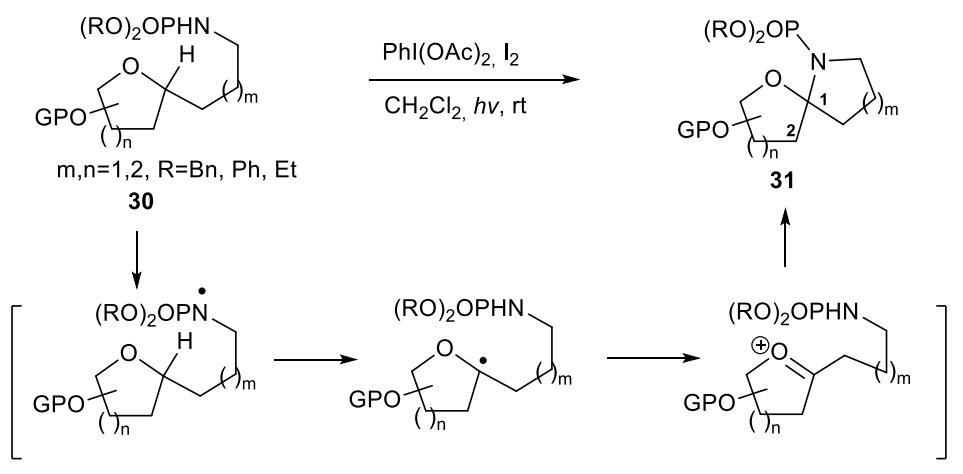<smiles>COCOPN1CCC[C@@]12OC(COC)[C@@H](OC)[C@H]2OC</smiles>

$31 a(64 \%)$

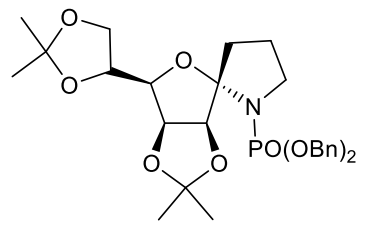

31b $(74 \%)$

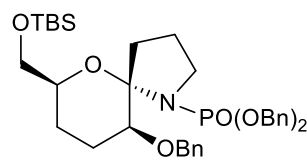

$31 \mathrm{c}(47 \%)$

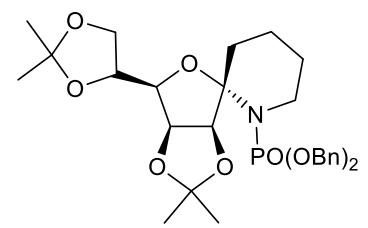

$31 \mathbf{d}(18 \%)$

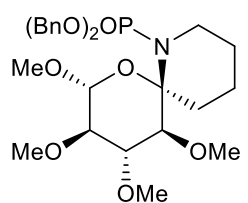

31e $(41 \%$, dr: $3 / 1)$

Scheme 6 Synthesis of 1-azaspirocycles $\mathbf{3 1}$ by intramolecular hydrogen atom transfer

The same group has applied the HAT strategy to the synthesis of spirolactams involving amidyl radicals [31] (Scheme 7). It is noteworthy that depending on the substitution at C-2, spirolactones or spirolactams are obtained. Indeed, 2deoxysugar 32a afforded lactam 33, whereas 2-acetyl-D-glucose 32b gave spirolactone 34 in good yield. This difference of reactivity is explained by the authors on the basis of the hard and soft acids and bases (HSAB) principle. In the case of 32b, the oxocarbenium ion intermediate is a harder electrophile than 32a due to the presence of the electron-withdrawing group at $\mathrm{C}-2$. As the oxygen atom of the amide is considered to be a harder nucleophile than the nitrogen atom, it attacks the hard electrophilic oxocarbenium ion. In the case of 32c, substituted at $\mathrm{C}-2$ with an electron-donating group, a mixture of spirolactam $\mathbf{3 5}$ and spirolactone 36 was obtained. The highly stereoselective formation of the products with axial $\mathrm{C}-\mathrm{O}(\mathrm{N})$ bonds is explained by a better stability of the bicyclic products $\mathbf{3 3 - 3 6}$ due to the anomeric effect. 


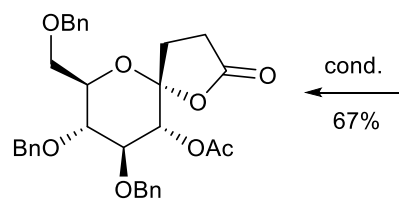

34<smiles>[R6]O[C@@H]1[C@@H](CO[OH2+])O[C@@H](CCC(N)=O)C([X])[C@H]1O[R6]</smiles>

32a $(X=\mathrm{H}, \mathrm{PG}=\mathrm{Me})$ 32b $(X=O A c, P G=B n)$

32c $(X=O M e, P G=M e)$

cond::

$\mathrm{Phl}(\mathrm{OAc})_{2}, \mathrm{I}_{2}$ $\mathrm{CH}_{2} \mathrm{Cl}_{2}, h v, \mathrm{rt}$<smiles>COC[C@H]1O[C@@]2(CCC(=O)N2)C[C@H](OC)[C@@H]1OC</smiles>

33<smiles>COC[C@H]1O[C@@]2(CCC(=O)N2)[C@@H](OC)[C@@H](OC)[C@@H]1OC</smiles>

$35,48 \%$

36, $32 \%$

Scheme 7 Synthesis of carbohydrate-based spirolactams or spirolactones by intramolecular hydrogen abstraction

Spirolactams have also been obtained from nitrosugars by way of Michael addition (Scheme 8) [32]. For example, reaction of nitrosugar 37 [33] with methyl acrylate in the presence of TBAF gave unstable adduct $\mathbf{3 8}$ which after column chromatography produced 39 in good yield $[32,34]$. On the other hand, azidation of the crude Michael adducts 38 with $\mathrm{TMSN}_{3}$ in the presence of TMSOTf afforded 1-azido sugar $\mathbf{4 0}$ in $90 \%$ yield as a single diastereomer. This methodology has also been applied to other electrophiles such as acrylonitrile or ethyl propiolate and in other sugar series (D-manno). Amides $\mathbf{4 1}$ and $\mathbf{4 2}$ were then obtained after reduction of 1-azido sugar $\mathbf{4 0}$ and subsequent cyclization. Ringopening of the transient glucosylamine intermediate formed during the process followed by ring-closing of the corresponding open imine led to the formation of a mixture of epimeric spirolactams 41 and 42 [32]. Deprotection of the benzyloxy groups afforded the final products $\mathbf{4 3}$ and $\mathbf{4 4}$ in 70\% yields from nitrosugar 37 . Related spiro-carbamate and spiro-sulfamate glycosides were obtained by means of intramolecular rhodium-catalyzed amination of pseudo anomeric $\mathrm{C}-\mathrm{H}$ bond in 2-deoxy $C$-glycosides [35]. 


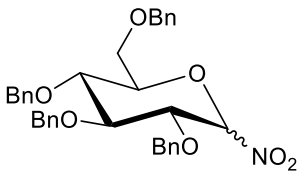

37<smiles>COC(=O)CCC(O)(OC(COCc1ccccc1)C(C)C)[C@H](Br)Oc1ccccc1</smiles>

39<smiles>COC(=O)CCC(OCc1ccccc1)(OCc1ccccc1)[C@@H](Br)OCc1ccccc1</smiles>

$90 \% \quad \mathrm{TMSN}_{3}, \mathrm{TMSOTf}$ $\mathrm{CH}_{2} \mathrm{Cl}_{2}$

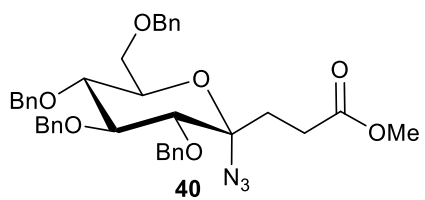

$$
\begin{array}{l|l}
78 \% & \mathrm{H}_{2}, \mathrm{Pd} / \mathrm{CaCO}_{3} \\
(\mathrm{dr} \mathrm{1/1)}) & \mathrm{EtOH}
\end{array}
$$
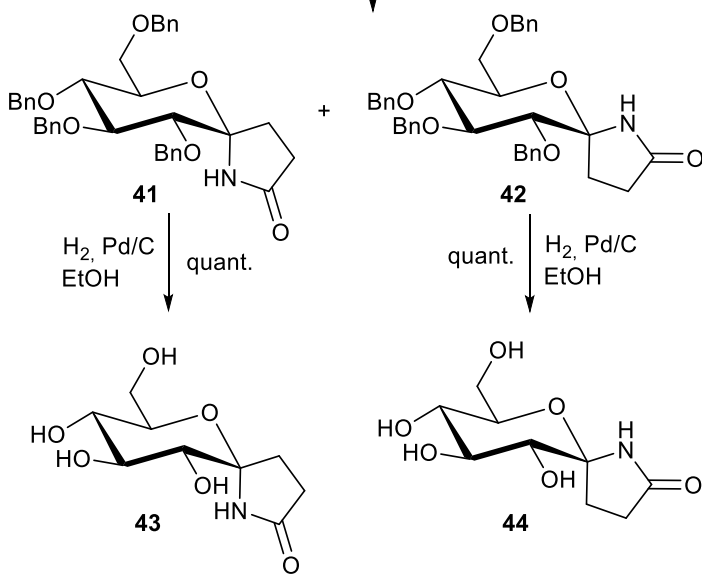

44

Scheme 8 Synthesis of carbohydrate-based spirolactams 43 and 44 from nitrosugar 37

Spiroaminals 45 and 46 were obtained following a similar strategy [32]. The inhibitory activities of compounds $\mathbf{4 3 - 4 6}$ were evaluated on several commercially available glycosidases (Fig. 3). These compounds showed no inhibition against yeast $\alpha$-glucosidase and Jack beans $\alpha$-mannosidase [32]. Among the spirolactams tested, compound $\mathbf{4 3}$ with a glucose core gave the most interesting result as a highly selective inhibitor of bovine $\beta$-galactosidase. 

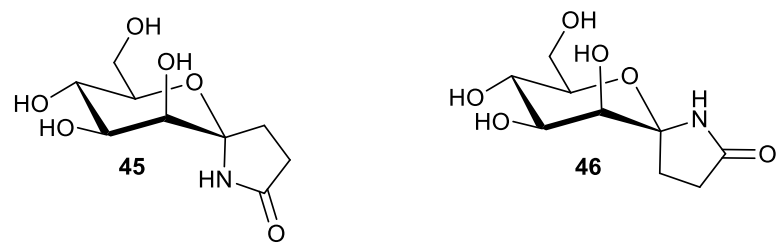

\begin{tabular}{lllll} 
& \multicolumn{4}{c}{$\mathrm{IC}_{50}(\mu \mathrm{M})$} \\
Enzyme & $\mathbf{4 3}$ & $\mathbf{4 4}$ & $\mathbf{4 5}$ & $\mathbf{4 6}$ \\
\hline$\alpha$-glucosidase (yeast) & $\mathrm{NI}$ & $\mathrm{NI}$ & $\mathrm{NI}$ & $\mathrm{NI}$ \\
$\beta$-glucosidase (almonds) & $\mathrm{NI}$ & 200 & $\mathrm{NI}$ & $\mathrm{NI}$ \\
$\alpha$-galactosidase (coffee beans) & $\mathrm{NI}$ & 77 & $\mathrm{NI}$ & $\mathrm{NI}$ \\
$\beta$-galactosidase (bovine) & 207 & 160 & $\mathrm{NI}$ & 400 \\
$\alpha$-mannosidase (Jack beans) & $\mathrm{NI}$ & $\mathrm{NI}$ & $\mathrm{NI}$ & $\mathrm{NI}$
\end{tabular}

Figure 3 Inhibition profile of spirolactams 43-46

Several authors prepared original spiroaziridines as valuable intermediates for the synthesis of carbohydrate derivatives of interest [17, 36-38]. In the course of their study on carbohydrate-based spiro 1,3-oxazolidinine-2-thiones, Tatibouët et al. reported the synthesis of spiroaziridines $\mathbf{5 1}$ and $\mathbf{5 3}$ (Scheme 9) [37]. The strategy was based on the stereoselective formation of cyanohydrin derivatives 49 and $\mathbf{5 0}$. The stereochemistry of the new stereogenic center could be controlled under kinetic or thermodynamic conditions from ketone 48, obtained after oxidation of alcohol 47 [37-39]. Reduction of nitriles 49 and $\mathbf{5 0}$ afforded, after spontaneous intramolecular cyclization, aziridines $\mathbf{5 1}$ and 53, respectively. However, amino alcohols $\mathbf{5 2}$ and $\mathbf{5 4}$ resulting from competing tosyl migration were also obtained in yields up to $33 \%$. 


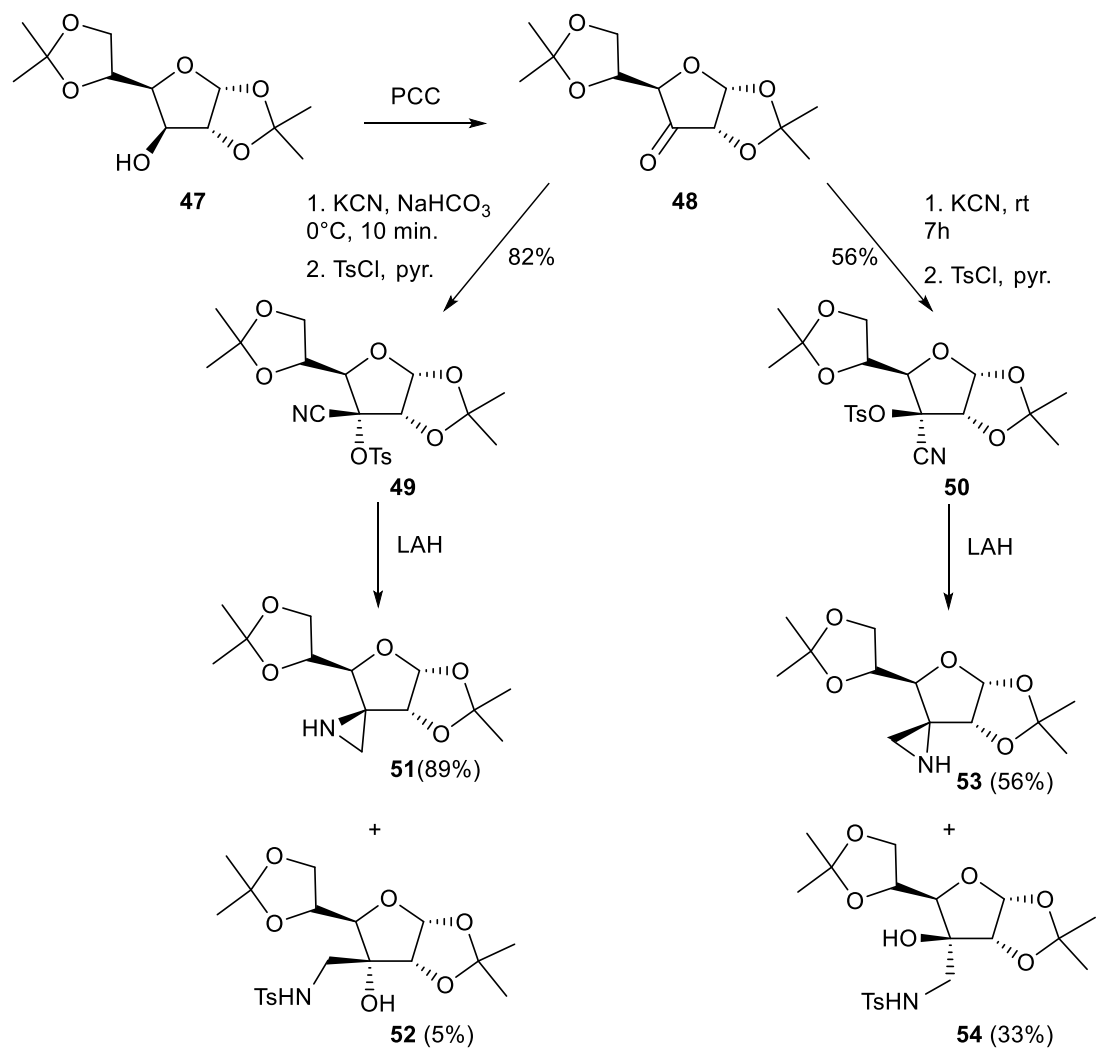

Scheme 9 Synthesis of spiroaziridines $\mathbf{5 1}$ and $\mathbf{5 3}$

\subsection{Systems with a nitrogen atom at $\beta$-position to the spirocyclic center}

Several authors have reported the formation of carbohydrates spiro-linked with an azetidine [40-43]. The first examples were described by the groups of Fuentes and Mandal in 2006 [40, 41a]. Fuentes and co-workers reported the formation of sulfoazetidine spiro- $C$-glycosides from ketose acetals [40]. For example, treatment of spiroacetal 55 obtained in 4 steps from D-fructose [44] with trimethylsilyl cyanide followed by reduction of the nitrile and dimesylation of the corresponding amino alcohol intermediate afforded compound 56 in 53\% yield (3 steps) [40,45]. Basemediated cyclization of $\mathbf{5 6}$ and deprotection of the resulting azetidine gave spiro iminosugar 58 in good yield (Scheme 10). 


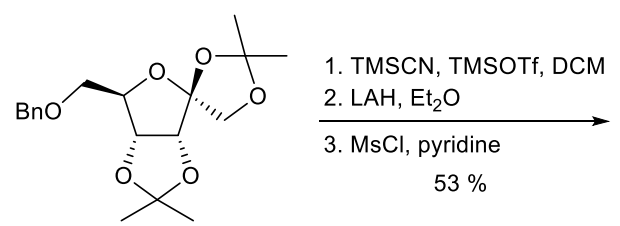

55

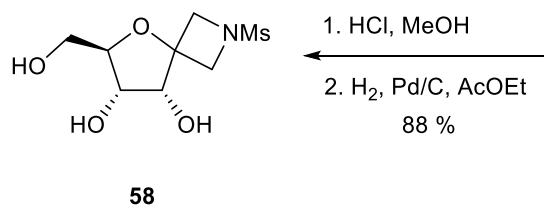

58

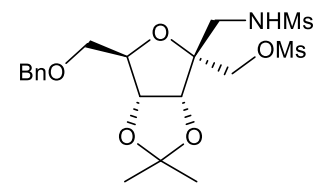

56

$63 \% \downarrow \mathrm{NaH}, \mathrm{DMF}$<smiles>CC1(C)O[C@@H]2[C@H](O1)C1(CNC1)O[C@@H]2COc1ccccc1</smiles>

Scheme 10 Synthesis of spiroazetidine 58

During their studies on the synthesis of spironucleosides [41], Mandal and coworkers reported the formation of nitrogen-containing spirosugars 61-63 through an aldol/Cannizzaro sequence (Scheme 11). Compound 59, easily obtained from 47, was treated by formaldehyde and sodium hydroxide to afford the corresponding diol which was then subjected to mesylation reaction with $\mathrm{MsCl}$ and $\mathrm{Et}_{3} \mathrm{~N}$ [41a]. The resulting dimesylate $\mathbf{6 0}$ was reacted with benzylamine providing spiroazetidine 61. After cleavage of the acetonide group and acetylation, a nucleobase could be introduced by treatment of compound $\mathbf{6 2}$ with 2,4-bis(trimethylsilyloxy)pyrimidine. Deacetylation and debenzylation steps furnished spironucleoside 63. Interestingly, during the debenzylation step using transfer hydrogenolysis with cyclohexene, introduction of an ethyl group on the amine was observed. The authors explained the formation of $N$-alkyl derivative $\mathbf{6 3}$ by the Pdcatalysed oxidation of ethanol to acetaldehyde. Free amine may then condense with acetaldehyde to form an iminium which could be reduced in situ [41b]. Spirocyclic $C$-glycosides $\mathbf{6 4}$ have been obtained by a related synthetic strategy using an aldol/Cannizzaro sequence (Scheme 11) [42]. These compounds have been evaluated as SGLT2 (Sodium Glucose Transporter of type 2) inhibitors. SGLT2 inhibitors are expected to display interesting therapeutic applications, in particular as anti-diabetic agents [42]. Evaluation of compounds 64 indicated that $64 \mathrm{~b}$ and 64c were potent and selective SGLT2 inhibitors. Azaspironucleoside 64a with $\mathrm{IC}_{50}$ values in the micromolar range was found to be up to 1500 -fold less potent as SGLT2 inhibitors than $\mathbf{6 4 b}$ and $\mathbf{6 4 c}$. 
<smiles>CC1(C)O[C@@H]2O[C@H](C=O)[C@H](O)[C@H]2O1</smiles>

59

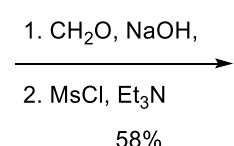

$58 \%$

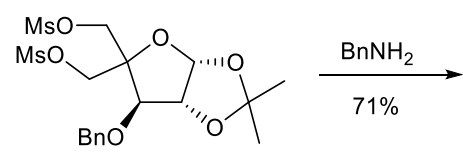

60

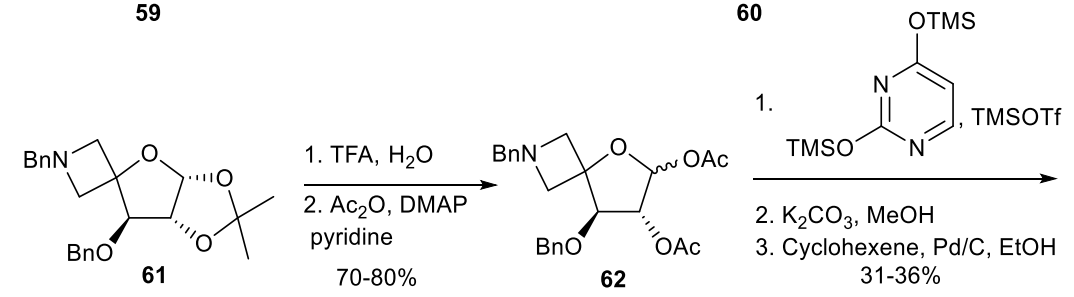<smiles></smiles>

63

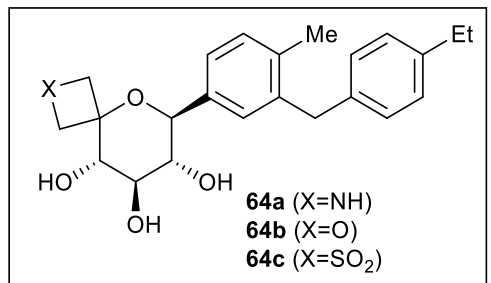

Scheme 11 Synthesis of spironucleosides 63 and 64 via Cannizzaro and cyclisation reactions

Related carbohydrates spiro-linked with an azetidine may be also obtained by means of Staudinger cycloaddition (Scheme 12) [43]. Acid chloride 65 was prepared from D-glucose in five steps and was used as a ketene precursor which can react with imines 67 to provide lactams $66 \mathbf{a}$ and $66 \mathbf{b}$ (d. r. 6/4 to 7/3 in favour of 66a). The $[2+2]$ cycloaddition reaction proceeded with a good level of stereoselectivity; only two d diastereomers were obtained among the four theoretically possible. The stereoselectivity observed could be rationalized by the torquoelectronic model.

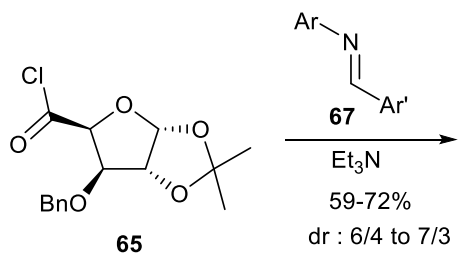

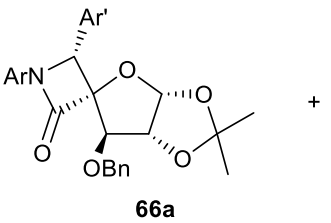

$\mathrm{Ar}=\mathrm{Ph}, 4-\mathrm{Cl}-\mathrm{Ph}, 4-\mathrm{Me}-\mathrm{Ph}, 4-\mathrm{OMe}-\mathrm{Ph}$ $\mathrm{Ar}^{\prime}=\mathrm{Ph}$, stiryl, $p$-tolyl, 4-OMe-Ph

Scheme 12 Synthesis of lactams 66 via Staudinger cycloaddition

Zhang and Schweizer reported the synthesis of carbohydrate-based azaspiranes with a piperidine or pyrrolidine moiety from 2,3,4,6-tetra- $O$-benzyl-Dgluconolactone (68) [46]. The first key step of the synthesis involved the highly diastereoselective TMSOTf-mediated $C$-glycosylation of the exocyclic glucose- 
based epoxyde 69 with allyltributylstannane (Scheme 13). The $\alpha$-selectivity observed may be rationalized by preferential nucleophilic attack along axial trajectory on the most favoured half-chair of the glycosyl cation intermediate $\mathbf{7 0}$ in which all the substituents are pseudo-equatorial. The resulting $C$-ketoside 71 was obtained in $80 \%$ yield. Conversion to the corresponding $\alpha$-amino ester $\mathbf{7 2}$ was performed by way of reductive amination. The iodocylisation reaction in the presence of molecular iodine turned out to be not completely regioselective; iodocompounds $\mathbf{7 3}$ and $\mathbf{7 4}$ were obtained in quantitative yield as an inseparable mixture of spirocyclic products of various ring sizes. Attack of the amino group at the most substituted site of the cyclic iodonium intermediate was found to be favoured and occurred without stereocontrol. Treatment of $\mathbf{7 3}$ and $\mathbf{7 4}$ with silver acetate followed by saponification of the resulting acetates afforded alcohols 75-76 that could be separated by flash chromatography. Their structures and stereochemistry were established in part by NMR analysis and NOE experiments. Pseudo iminosugars $\mathbf{7 7}$ were finally obtained after deprotection of spirocyclic pyrrolidines $\mathbf{7 5}$ in the presence of Pearlman's catalyst. The authors reported also the synthesis of analogues of 77 in which the primary alcohol of the D-glucose moiety has been replaced by an amine $[46 b]$. 


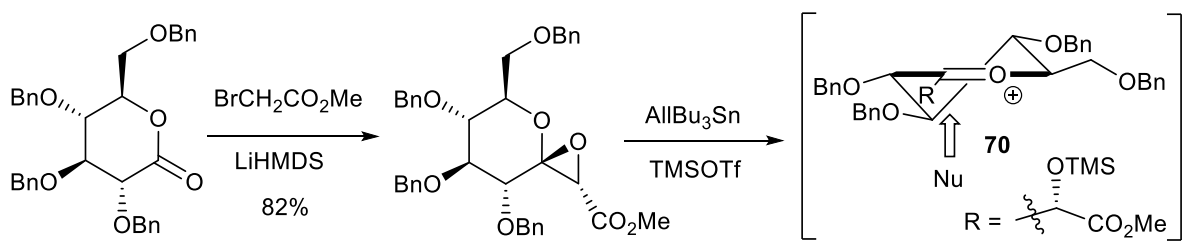

68

69<smiles>C=CC[C@]1([C@@H](O)C(C)=O)O[C@H](COCc2ccccc2)[C@@H](OCc2ccccc2)[C@H](O)[C@H]1OCc1ccccc1</smiles><smiles>C=CC[C@]1([C@@H](Cc2ccccc2)C(C)=O)O[C@H](COCc2ccccc2)[C@@H](OCc2ccccc2)[C@H](O)[C@@H]1OCc1ccccc1</smiles><smiles>CC(C)C</smiles>

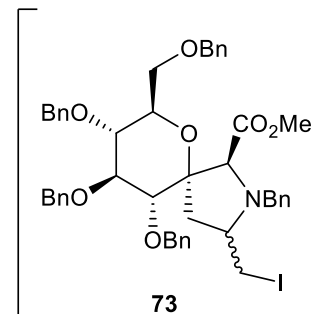<smiles></smiles>
2. $\mathrm{K}_{2} \mathrm{CO}_{3}$<smiles></smiles>

77a $\mathrm{R}_{2}=\mathrm{CH}_{2} \mathrm{OH}, \mathrm{R}_{3}=\mathrm{H}$ 77b $\mathrm{R}_{2}=\mathrm{H}, \mathrm{R}_{3}=\mathrm{CH}_{2} \mathrm{OH}$<smiles>[R]C1([R3])C[C@]2(O[C@H](COCc3ccccc3)[C@@H](O)[C@@H](O)[C@@H]2O)[C@H](C(=O)O)N1Cc1ccccc1</smiles>

75a $\mathrm{R}_{2}=\mathrm{CH}_{2} \mathrm{OH}, \mathrm{R}_{3}=\mathrm{H}$ (43\%) 75b $\mathrm{R}_{2}=\mathrm{H}, \mathrm{R}_{3}=\mathrm{CH}_{2} \mathrm{OH}(46 \%)$

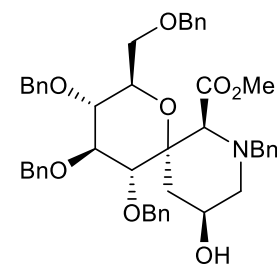

$76(7 \%)$

Scheme 13 Synthesis of spiroiminosugars via iodocyclisation

Ring-closing metathesis (RCM) is one of the most powerful methods to access amine-containing heterocycles in particular for the formation of medium or large rings [47]. The group of Vankar has used this methodology for the formation of oxa-aza spiro sugars containing a piperidine or azepane ring (Scheme 14) [48]. Intermediates 78 were prepared from gluconolactone $\mathbf{6 8}$ by addition of vinyl- or allylmagnesium bromide. $C$-glycosylation using trimethylsilyl cyanide in the presence of TMSOTf afforded nitriles $\mathbf{7 9}$ in good yields and high diastereoselectivity. Key RCM precursors $\mathbf{8 0}$ were then synthesized following a 3-step sequence: reduction of nitrile group, protection of the resulting amine and $\mathrm{N}$-allylation. Ring 
closing metathesis of dienes $\mathbf{8 0}$ gave the corresponding azacycles $\mathbf{8 1}$ in good yields. It is noteworthy that compound 81a was not formed in the presence of Grubbs I catalyst. Substantial substrate reactivity differences were also observed for the dihydroxylation step. Whereas treatment of $\mathbf{8 1 b}$ with osmium tetroxyde in the presence of $N$-methyl morpholine- $N$-oxide (NMO) provided diol $\mathbf{8 2} \mathbf{b}$ in good yield and as a single diastereomer, no conversion was observed when the same conditions were applied to piperidine 81a. To overcome this lack of reactivity, bishydroxylation was performed with $\mathrm{RuCl}_{3}$ in the presence of $\mathrm{NaIO}_{4}$ and $\mathrm{CeCl}_{3}$ to give the expected diol which was directly acetylated, and then deprotected to afford 82a in 53\% yield for the three steps. Spiro iminosugars $\mathbf{8 3}$ were obtained after debenzylation. A related synthetic strategy was used for the formation of lactams 84. Evaluation of spiro compounds 83-84 as inhibitors of a panel of five glycosidases indicated that $\mathbf{8 3}$ were weak but selective inhibitors of Jack beans $\alpha$ mannosidase. Furthermore lactams $\mathbf{8 4}$ showed no inhibition or inhibition in the $\mathrm{mM}$ range.

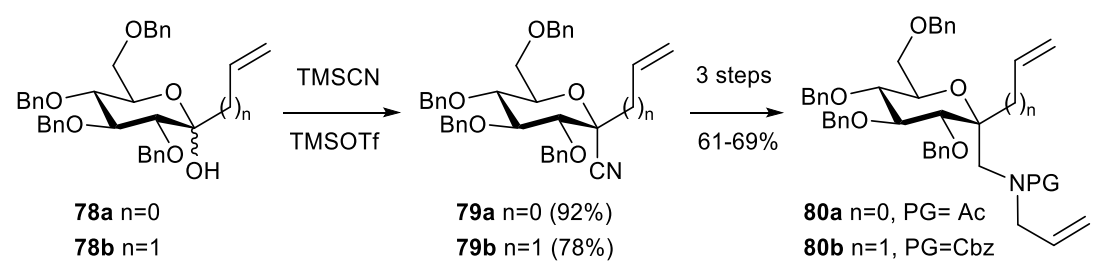

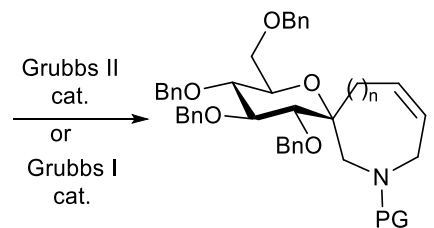

81a $n=0, P G=A c(72 \%)$

81b $n=1, P G=C b z(88 \%)$

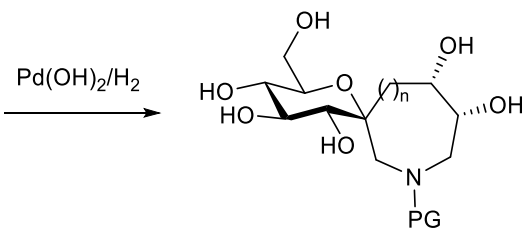

83a $n=0, P G=A c$ (quant.)

83b $n=1, P G=H(76 \%)$

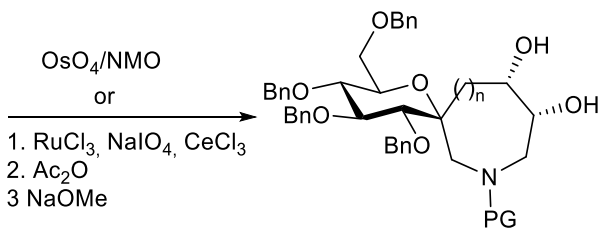

82a $n=0, P G=A c(53 \%)$

82b $n=1, P G=C b z(85 \%)$

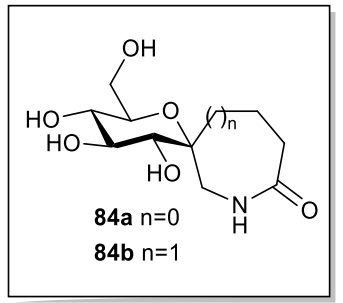

Scheme 14 Synthesis of spiroiminosugars via ring-closing metathesis 


\section{Iminosugars Spiro-linked with Carba, Oxa and Azacyles}

In addition to the structures presented before, in which an aza-cycle is attached to a polyhydroxylated scaffold, spiro compounds featuring a nitrogen-containing heterocyclic polyol have also attracted great attention. Aside from compounds $\mathbf{2 4}$ (Scheme 4) and 83 (Scheme 14) encompassing multiple $\mathrm{OH}$ on both the $\mathrm{N}$ and $\mathrm{X}$ $(\mathrm{X}=\mathrm{C}, \mathrm{O})$ cycles, a number of additional spiro-iminoalditols have been built in an attempt to affect the peculiar biological properties of their monocyclic templates. Simple aminocyclitols are usually tailored to adapt the catalytic site of a given glycoenzyme, mimicking the corresponding glycoside to be processed [2]. Spirolinked iminoalditols might be structurally related to fused bicyclic iminosugars (Fig. 1) however, the peculiar orthogonal orientation of the extra spiro-cycle offers scope for unprecedented interactions in the active site. Furthermore, synthetic issues to access the two kinds of adjoined cycles are rather distinct. Contrarily to their fused analogues [47a, 49], the construction of spirocyclic iminoalditols has been scarcely reviewed [50]. Main strategies are described below.

\subsection{Iminosugar-carbacycle spiro systems}

L-Fucose and L-rhamnose are 6-deoxyhexoses commonly found in complex carbohydrates from all organisms, the trimming of which is performed by fucosidases and rhamnosidases. Simple iminosugars featuring both the methyl substituent and the adequate hydroxyl distribution are generally potent inhibitors of these enzymes. Analogues with a spiro carbacycle in place of the C-5 methyl group have been designed in order to evaluate the tolerance of the corresponding binding pocket to steric strain and to improve either potency or hydrophobicity. To access spirocyclopropyl iminosugars in L-fuco or L-rhamno series, the group of Behr applied a Kulinkovich-Szymoniak-Bertus cyclopropanation of designed glycononitriles. This reaction of very wide application [51] is based on the generation of a titanacyclopropane intermediate, a bis-anionic reactive species able to add twice to the $-\mathrm{CN}$ electrophilic partner to afford a spirocyclopropyl primary amine (Scheme 15). Hence, D-lyxose or L-arabinose derived nitriles $\mathbf{8 5}$ or $\mathbf{9 0}$, gave linear cyclopropylamines $86(80 \%)$ and $91(49 \%)$, the latter being formed after in situ $\mathrm{Bz}$ transfer $[52,53]$. A game of protection/deprotection combined with activation of the primary hydroxyl to induce intramolecular nucleophilic displacement furnished the expected spirocyclopropyl piperidines 89 and 94, analogues of Lrhamnose and L-fucose, respectively. Unsaturated pyrroline 95 was obtained from intermediate $\mathbf{8 7}$ after oxidative cleavage of the free vicinal diol and isopropylidene deprotection. The same synthetic sequence was applied for the preparation of $\mathbf{9 6}$, the C-3 epimer of 95, from 92. Spirocyclopropyl-iminosugars showed some activi- 
ty against fucosidase and rhamnosidase, best results being obtained with 94 ( $K_{\mathrm{i}}=18 \mu \mathrm{M}$ against $\alpha$-fucosidase from bovine kidney).

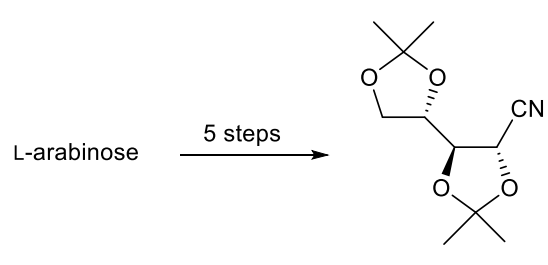

85
$\mathrm{EtMgBr}, \mathrm{TiMe}(\mathrm{O} i-\mathrm{Pr})_{3}$

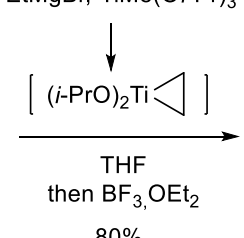

$80 \%$

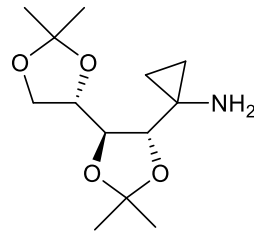

86 1. concd $\mathrm{HCl}$ in $\mathrm{EtOH}-\mathrm{H}_{2} \mathrm{O}$
2. $(\mathrm{Boc})_{2} \mathrm{O}, \mathrm{NEt}_{3}$
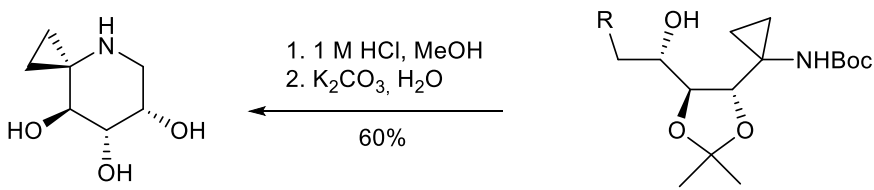

89

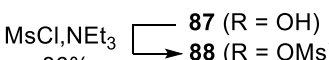
$86 \%$

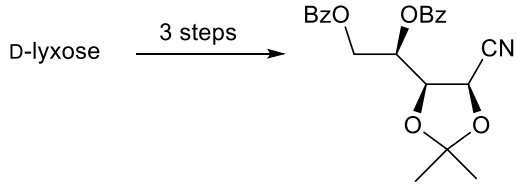

90

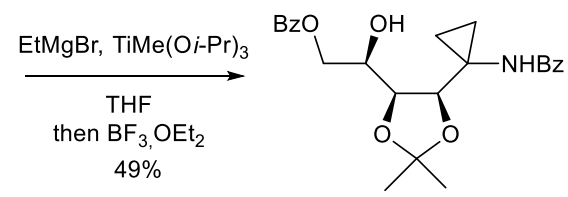

91

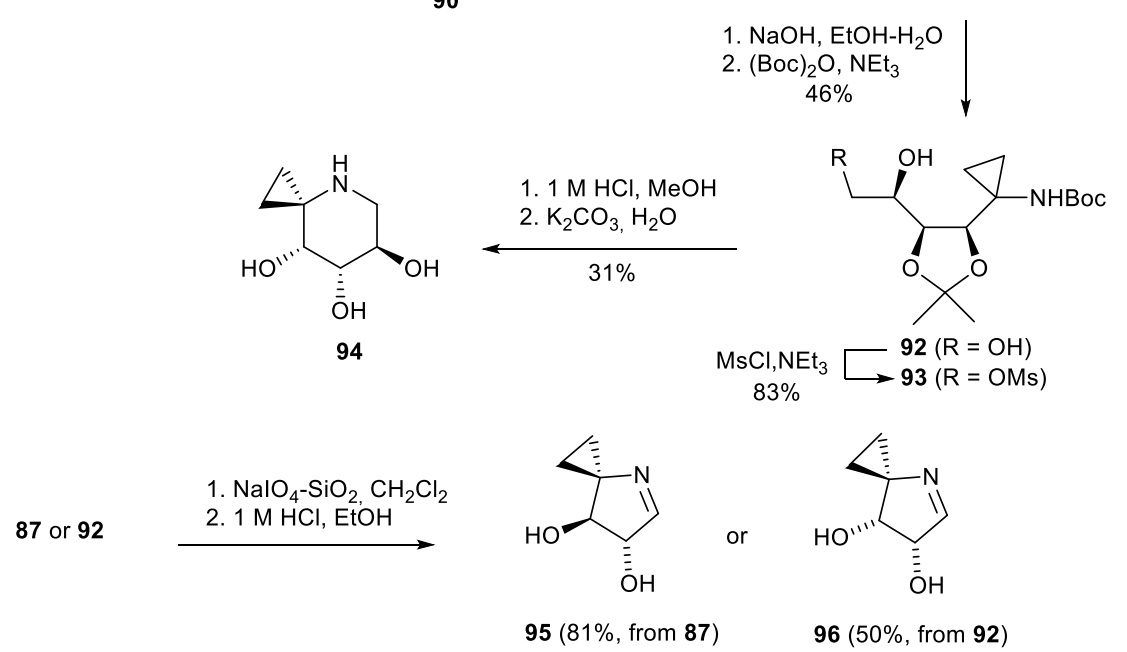

Scheme 15 Synthesis of spiroiminosugars from glycononitriles 
To access spirocyclopropyl pyrrolidines, the same group adapted their strategy to 4-methanesulfonyl-glycononitriles such as 97 (Scheme 16), the cyclopropanation of which was accompanied by concomitant cyclization [54,55]. By this very straightforward method spirocyclopropyliminocyclitol 99 was obtained in only five steps starting from D-mannose. Further stereoisomeric pyrrolidines of general structure $\mathbf{1 0 0}$ were prepared following the same strategy through variation of the starting sugar. Among these, only 99 showed inhibition potency in the micromolar range $\left(K_{\mathrm{i}}=1.6 \mu \mathrm{M}\right.$ against $\alpha$-fucosidase from bovine kidney). In general, biological assays with such compounds suggest that the replacement of a methyl substituent by a spirocyclopropyl group reduces the inhibitory potency towards the corresponding enzymes.

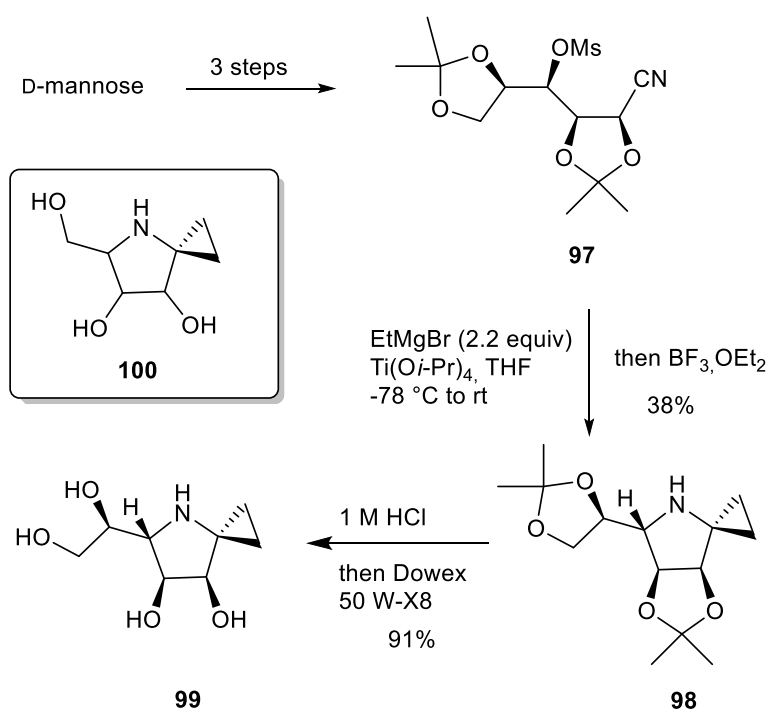

Scheme 16 Synthesis of spiroiminosugar 99

A spirocyclohexyl analogue of $\mathbf{9 9}$ was synthesized more recently in the racemic series from a hydroxyalkyldihydropyrrole precursor [56]. Elaboration of these latter substances involved the coupling of propargylamines with $\alpha$-chloroaldehydes, followed by alkyne reduction and one-pot epoxide formation/ring-opening sequence (Scheme 17). Thus, the alkynyl chlorohydrin 102 was prepared first following addition of Boc-protected propargylamine 101 to 2-chlorocinnamaldehyde. Then, Lindlar reduction followed by acidic treatment of the crude product afforded the expected dihydropyrrole $\mathbf{1 0 3}$ in good overall yield (78\%) after neutralization. It was then converted into spirocyclohexyl-iminosugar 104 via reaction with phosgene and subsequent dihydroxylation. The relative stereochemistry of final compound 104 was assessed by 1D NOESY spectra. 

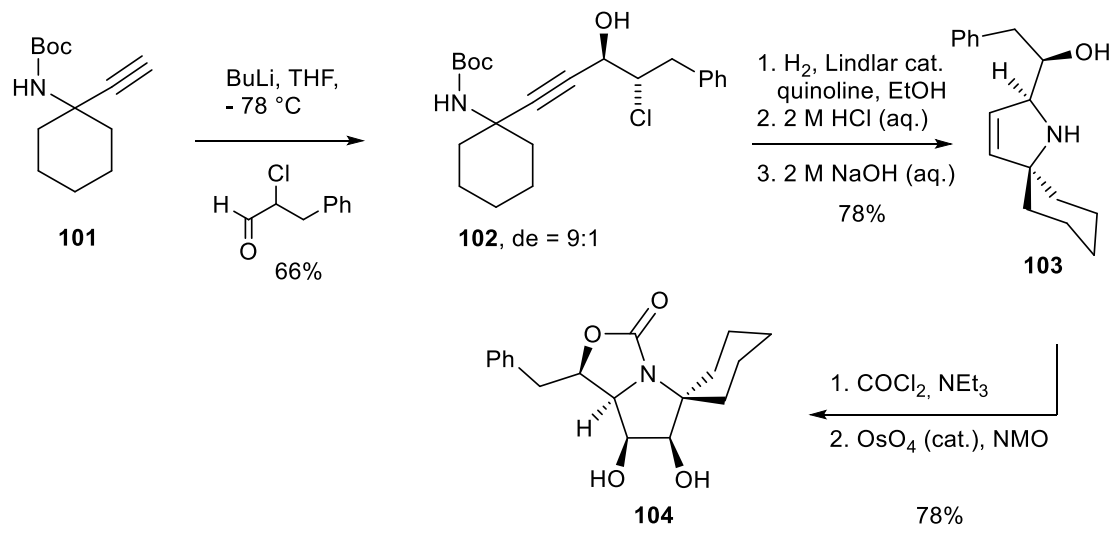

Scheme 17 Synthesis of spirocyclohexyliminosugar 104 via dihydropyrrole intermediate

In such aza-spiroheterocycles, partial hydroxylation of the hydrocarbon portion could afford new binding contributions to improve inhibition potencies against a given enzyme. Therefore, Pinto and Chen prepared swainsonine analogue 110 (Scheme 18), which was expected to interact strongly with the hydrophobic pocket of Tyr727, Phe206 and Trp415 in Drosophila Golgi $\alpha$-mannosidase II [57]. The key quaternary center was formed stereoselectively by aldol condensation of ketone 105 with $(R)$-isopropylidene glyceraldehyde 106 and subsequent acylation. From the four possible stereoisomers (ratio 30:6:5:1), the desired compound 107 was isolated by silica gel chromatography and reduced/acylated to obtain 108 . A Curtius rearrangement allowed the introduction of the amine-derived functional group at this stage, affording carbamate 109. Additional standard procedures comprising ring closure by intramolecular nucleophilic displacement delivered target compound 110. Unfortunately, it did not show effective inhibition of human maltase glucoamylase or Golgi mannosidase II.<smiles>O=C(Br)C1CCCC1=O</smiles>

105<smiles>CC1(C)OCC(C=O)O1</smiles><smiles>[134IH]</smiles>
2. $\mathrm{Ac}_{2} \mathrm{O}$, pyridine $36 \%$<smiles>CC(=O)OC([C@H]1COC(C)(C)O1)C1(C(=O)O)CCCC1=O</smiles>

107

1. $\mathrm{NaBH}_{4} \mathrm{MeOH}$ 2. $\mathrm{Ac}_{2} \mathrm{O}$, pyridine $71 \%$

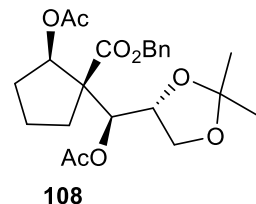

108

110

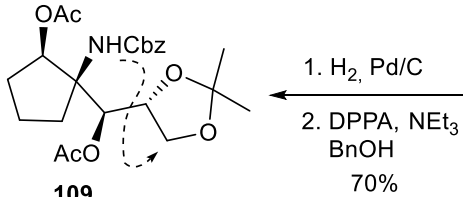

Scheme 18 Synthesis of swainsonine analogue 110 via Curtius rearrangement 
An analogue of 110, the bis-spiranic $\mathrm{C}_{2}$-symmetric pyrrolidine 117, was successfully synthesized by Morozov et al. via iterative nitrone chemistry [58]. As depicted in Scheme 19, quaternization of the two $\alpha$-carbon atoms resulted from successive completely regio- and stereoselective organometallic addition and intramolecular cycloaddition reactions on nitrones 111 and 116. Transient oxidation of hydroxylamine $\mathbf{1 1 2}$ proved however moderately regioselective, affording the two isomeric nitrone intermediates 113 and 114. Following the iterative synthetic strategy, tert-butoxy protected dispiro-pyrrolidine 117 was eventually obtained in reasonable overall yield.

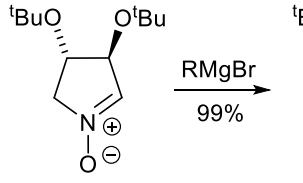

111

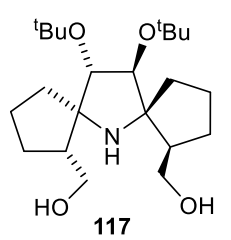<smiles>[2H]C1C([18OH])CN(O)C1[18OH]</smiles>

$112 \mathrm{R}=\left(\mathrm{CH}_{2}\right)_{3} \mathrm{CH}=\mathrm{CH}_{2}$

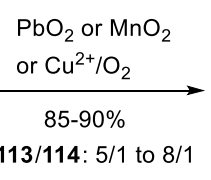

'Bu

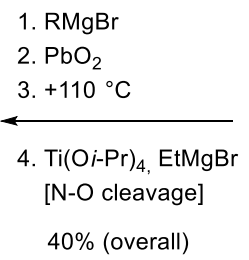<smiles>CCCCO[C@H]1C=[N+]([O-])[C@@H](F)[C@@H]1OCCC</smiles>

113<smiles>[R]C1=[N+]([O-])C[C@H](OCCC)[C@H]1OCCC</smiles>

114 (minor)

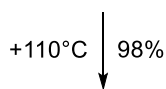<smiles>CCCCO[C@H]1C=[N+]([O-])[C@H](OCCC)C12CCC[C@H]2CO</smiles>

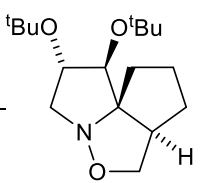

115

Scheme 19 Synthesis of bis-spiranic pyrrolidine 117 via iterative nitrone chemistry

Jarosz and co-workers prepared a series of highly hydroxylated spiro-iminosugars, i. e. azaspiro[4.5]decanes $\mathbf{1 2 1}$ and 123, using a double addition of allyl Grignard to polyhydroxylated $\omega$-bromonitrile 118 (Scheme 20) [59]. While monoallylated product was isolated in good yields when 1.3 equivalents of allylMgBr were used, the reaction with 5 equivalents of this same reagent afforded the bis-allylated piperidine 119 in $70 \%$ yield. The presence of DMPU or HMPA clearly favoured the addition of a second allyl nucleophile to the putative imine intermediate [60]. Protection of the free NH proved somewhat tricky due to the presence of bulky substituents in the proximity of the nitrogen atom. However 119 was efficiently protected as a trifluoroacetate, which was subsequently subjected to RCM (Grubbs-II catalyst) to afford azaspiro[4.5]decene 120. Upcoming osmylation of $\mathbf{1 2 0}$ with osmium tetroxide and $N$-methyl morpholine- $N$-oxide (NMO) was completely stereoselective and the configuration of the formed diol 121 was firmly assigned by $\mathrm{X}$-ray analysis of a hexaacetate derivative. RCM was also applied to amine 119 by using transient in situ protection with a Brønsted acid. Interestingly, osmylation occurred from the opposite face with spirodecene $\mathbf{1 2 2}$ than it did in the case of 
olefin 120, the free amine certainly acting as a directing group in such transformations.

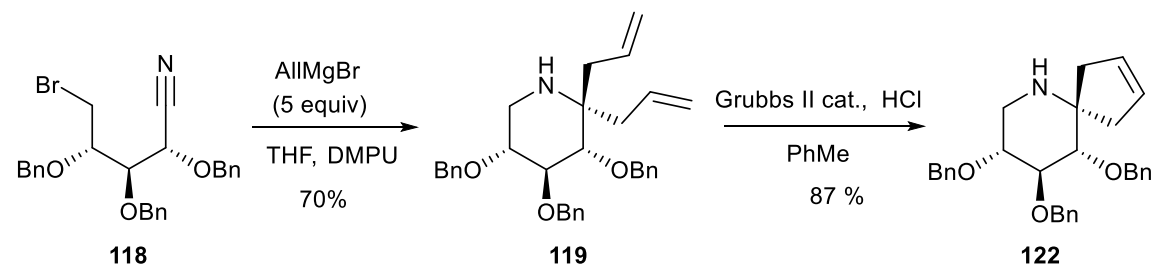

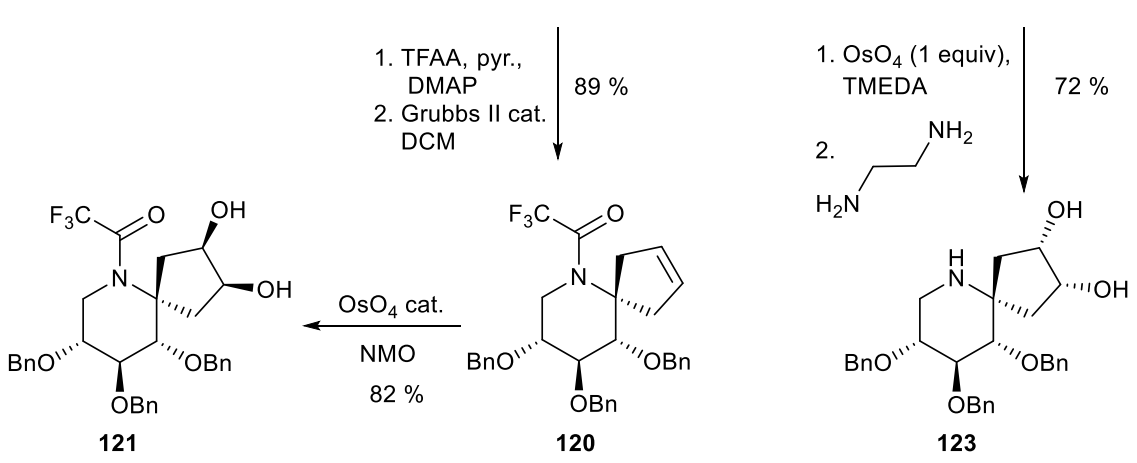

Scheme 20 Synthesis of azaspiro[4.5]decanes 121 and 123 via RCM

Finally, spirocycles were also installed at the nitrogen atom of iminosugars to generate a permanent positive charge (as a quaternary ammonium salt) in order to favour ionic interactions at the catalytic site of glycosidases [61]. To this end, a double nucleophilic substitution reaction on tetrabenzylated DNJ 124 with either 1,4-dibromobutane or 1,5-dibromopentane followed by hydrogenolysis afforded $\mathrm{N}$-spirofused iminosugars 126a,b (Scheme 21). An analogous strategy gave 1deoxynojirimycin derivatives $\mathbf{1 2 7}$ and $\mathbf{1 2 8}$ with isoindoline and morpholino extra rings, respectively. The glycosidase inhibition activities of the bromide salts of 126-128 were evaluated at $500 \mu \mathrm{M}$ concentration on various commercially available glycosidases from different natural origins ( $\alpha$-mannosidase from Jack bean, $\alpha$ glucosidase from $S$. cerevisiae, amyloglucosidase from $A$. niger). Best results were obtained with 126b for which $30 \%$ residual activity was observed towards amyloglucosidase. Ammonium salts are also frequently used as antibacterial agents, disrupting cell membranes through ionic interactions. Therefore, along with their antiglycosidase potential, antibacterial effect of $N$-spirofused iminosugars was evaluated on the Gram positive $S$. aureus and the Gram negative E. coli. However, no activity against the two selected microorganisms could be detected up to $5 \mu \mathrm{M}$. 


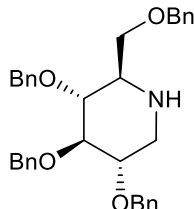<smiles>BrCCCCCBr</smiles>
$\mathrm{K}_{2} \mathrm{CO}_{3}, \mathrm{DMF}, 80^{\circ} \mathrm{C}$ 124<smiles>OCC1[C@H](O)[C@@H](O)[C@@H](O)CN1Cc1ccccc1</smiles>
127

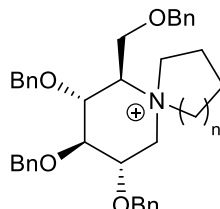<smiles>COCCOCCO</smiles>

$$
\mathrm{n}=1,125 \mathrm{a}(86 \%)
$$
$n=2,125 b(74 \%)$<smiles>OCCN1C[C@H](O)[C@H](O)[C@@H]1CO</smiles><smiles></smiles>

$$
n=1,126 a(100 \%)
$$
$n=2,126 b(96 \%)$

Scheme 21 Synthesis of $N$-spirofused derivatives of DNJ

Compound 128 prepared by the same method differs from its congeners by the presence of an oxygen atom in the additional spirocycle. Other examples of such iminosugars with an adjoining oxa-cycle are given in the next section below.

\subsection{Iminosugar-oxacycle spiro systems}

In medicinal chemistry, hybrid drugs in which two pharmacophores are present in one molecule have attracted a great deal of interest. The resulting molecule might show dual therapeutic mechanism with possible synergism in bio-activity. In this direction, some iminosugars tethered with additional pharmacophores have been prepared to improve or localize the delivery of an anticancer-active iminosugar [62]. Dhavale and co-workers designed a series of azepines and piperidines spirolinked with morpholine-fused 1,2,3-triazole, which combine the glycosidase inhibitory potency of the iminosugar platform with the antifungal potential of the 1,2,3triazole pharmacophore [63]. Quaternization of the C-3 carbon of D-glucose affords unstable 1,2;5,6-di- $O$-isopropylidene-3- $O$-propargyl-3-azido-Dglucofuranose 129, prone to intramolecular azide-alkyne cycloaddition (AAC) at ambient temperature [64]. The triazole $\mathbf{1 3 0}$ thus obtained is a pivotal intermediate in the synthesis of the targeted compounds (Scheme 22). Access to the morpholino-piperidines required the installation of an azido function at C-5 of the D-gluco moiety yielding 131, or $\mathbf{1 3 4}$ when azidation was coupled with periodate degradation. Amination of the anomeric carbon under reductive conditions afforded the expected spirofused piperidines 132a and 135a, which were $N$-alkylated further to generate the library of compounds $\mathbf{1 3 2} \mathbf{b}-\mathbf{g}$ and $\mathbf{1 3 5 b} \mathbf{b}$. Their glycosidase inhibitory and antifungal activities were evaluated. Compounds 132a $\left(\mathrm{IC}_{50}=0.075 \mu \mathrm{M}\right)$ and $135 \mathrm{a}\left(\mathrm{IC}_{50}=0.036 \mu \mathrm{M}\right)$ showed potent $\alpha$-glucosidase (rice) activity when 
compared to the standard miglitol $\left(\mathrm{IC}_{50}=0.100 \mu \mathrm{M}\right)$ and proved highly active against Candida albicans yeast cells with minimum inhibition concentration $(\mathrm{MIC})=0.85 \mu \mathrm{M}$ and $\mathrm{MIC}=0.025 \mu \mathrm{M}$, respectively.

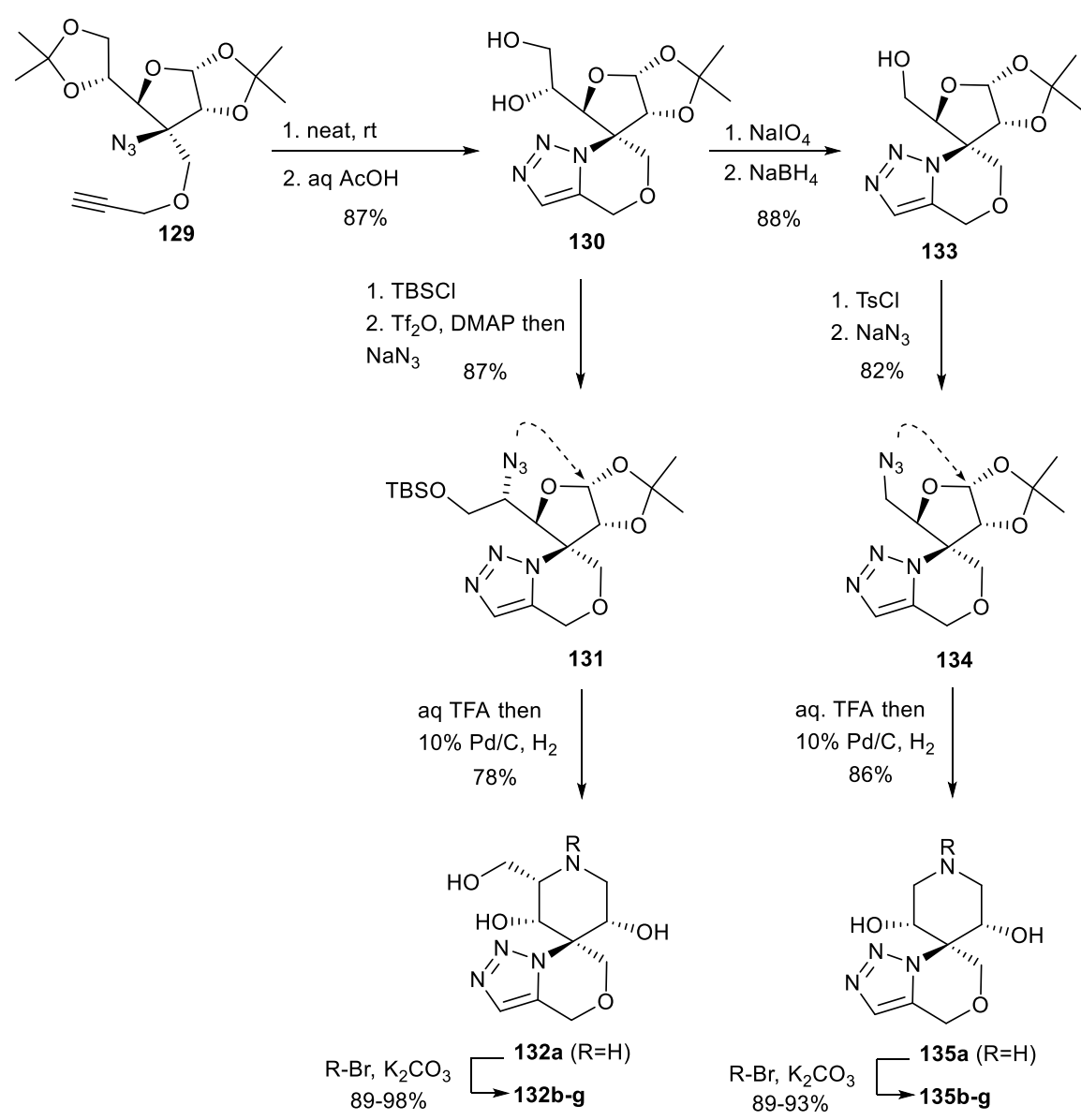

R=ethyl (b), butyl (c), hexyl (d), octyl (e), decyl (f), dodecyl (g)

Scheme 22 Synthesis of morpholino-piperidines via intramolecular AAC

Alternatively, other spiroiminosugar-oxacycle molecules were obtained, rather as reaction intermediates. Thus, during their study on metal-catalyzed reactions of $\alpha$ diazo- $\beta$-hydroxyamino esters such as 136, Py and co-workers observed the unexpected formation of the spirotetrahydrofuran 137 in $36 \%$ yield in the presence of a copper catalyst (Scheme 23) [65]. The compound arose from $\mathrm{C}-\mathrm{H}$ insertion of the transient carbenoid into a benzylic $\mathrm{C}-\mathrm{H}$ bond of the nearby $\mathrm{OBn}$ substituent. 
Regioselective ring-opening of functionalized aziridines has been exploited by Eum et al. for the synthesis of pyrrolizidines and indolizidines [66]. During the synthesis of a non-natural analogue of castanospermine, the spiro-hemiaminal intermediate $\mathbf{1 4 0}$ could be isolated and characterized (Scheme 23). The treatment of aziridine $\mathbf{1 3 8}$ in strongly acidic media afforded aziridinium 139 through intramolecular hemiaminal/hemiacetal formation. A subsequent nucleophilic opening reaction with water from the less hindered $s i$-face at the more substituted carbon gave spiro-piperidine $\mathbf{1 4 0}$ which was further transformed into the targeted indolizidine.<smiles>CCOC(=N)[C@]1(COCc2ccccc2)[C@H](O)[C@H](O)[C@H](c2ccccc2)N1O</smiles>

136

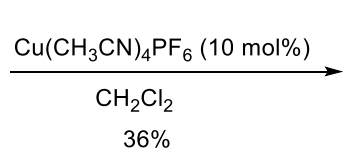
$36 \%$

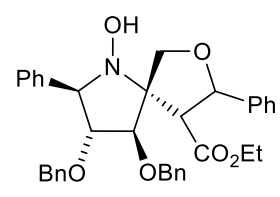

137

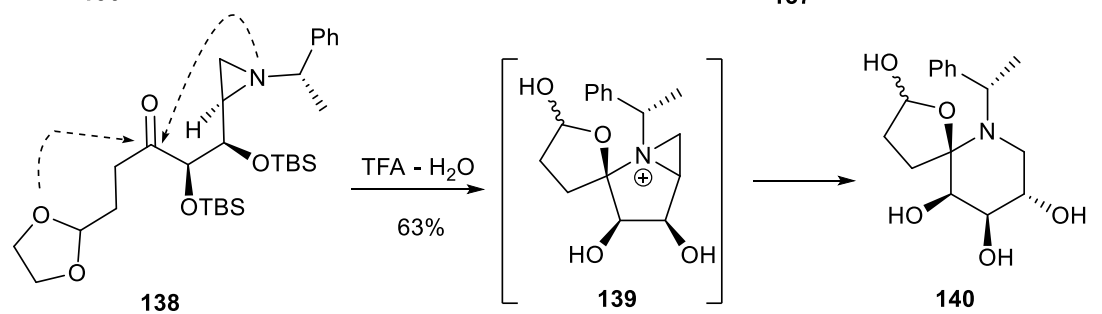

Scheme 23 Synthesis of spiroiminosugar-oxacycles 137 and 140

\subsection{Iminosugar-azacycle spiro systems}

The synthesis of a new class of diazaspiro-iminosugars has been reported by Dhavale and co-workers, the structures of which comprise a nitrogen atom in both rings [67]. Diazaspiro skeleton is an important structural motif in biologically active molecules as exemplified by spirocyclic pyrrolidone 141, a HIV-1 protease inhibitor [68], or the NK1 receptor antagonist 142 [69]. Glucose-derived azido compound 143 with a geminal $\alpha, \beta$-unsaturated ester was used as building block to access the expected spirolactams 145-148 (Scheme 24). Intramolecular lactamization occurred spontaneously after azide reduction, to furnish the spiro- $\gamma$-lactam 144 after selective 5,6-O-acetonide hydrolysis. This key intermediate was then converted into the targeted iminosugars following strategies analogue to those described in Scheme 22. Spiro-bislactams 146 and 148 were obtained by additional Schmidt-Boyer-Aube rearrangement that took place between azide and carbonyl functions in an intramolecular fashion. Glycosidase inhibitory activity of diazaspiro-iminosugars 145-148 was studied against $\alpha$-mannosidase (Jack bean), $\alpha$ - 
galactosidase (green coffee bean) and $\alpha$-glucosidase (yeast). Strong inhibition of the galactosidase occurred with $147\left(\mathrm{IC}_{50}=0.029 \mu \mathrm{M}\right)$, whereas 148 was a potent inhibitor of Jack bean $\alpha$-mannosidase $\left(\mathrm{IC}_{50}=0.080 \mu \mathrm{M}\right)$.

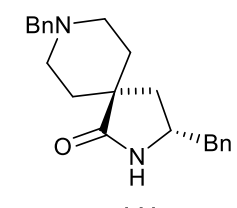

141

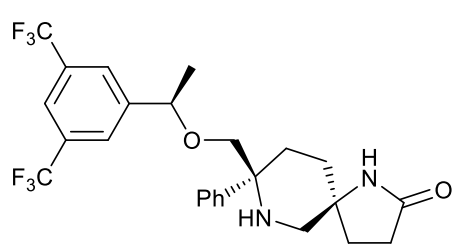

142<smiles>CCOC(C)=C[C@]1(N)[C@H]2OC(C)(C)O[C@@H]2O[C@H]1[C@H]1COC(C)(C)O1</smiles>

143<smiles>C[C@@H]1O[C@@H]([C@H](O)CO)[C@@]2(CCC(=O)N2)[C@H]2OC(C)(C)O[C@H]12</smiles><smiles>O=C1CC[C@@]2(N1)[C@H](O)C(=O)NC[C@H]2O</smiles>

146

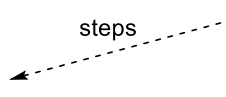

144 145

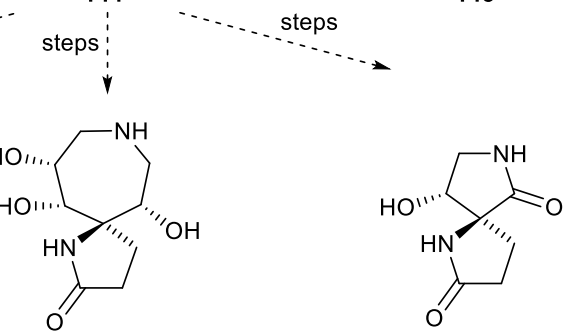

147

148

Scheme 24 Synthesis of diazaspiroiminosugars 145-148

\section{Conclusion and Outlook}

Nitrogen-containing analogues of carbohydrates are not only important in medicinal chemistry as therapeutic agents and as biological tools to study carbohydrateprocessing enzymes, but they represent also fascinating chemical targets for synthetic organic chemists. A number of novel methodologies have found application in the synthesis of unprecedented iminosugar-like structures. As a consequence, a growing number of non-natural amino-polyols have emerged in the literature, presenting a wide spectrum of chemical profiling. Among them, spiro-iminosugars have the unusual particularity to merge sub-structures by means of a quaternary apical carbon in almost perpendicular planes. The design and synthesis of aza spirocycles has been largely guided by this distinctive structural feature enabling 
conformational diversity and unprecedented interactions with biological receptors. As exemplified in this chapter, the main issue to be addressed during the synthesis of spiro-iminosugars is the installation of the pivotal quaternary spiro-atom. It might rarely originate from the starting material but it is mostly elaborated throughout the synthesis prior to or concomitantly with cyclization. On a biological point of view, in some cases the extra ring hinders recognition for a given target due to deleterious steric interactions. But, encouragingly, some aza spirocycles showed more potent or at least distinct biological activities than their nonspirocyclic homologues. This feature should stimulate research and innovation for the development of further structures of this kind to complement the repertoire of iminosugar analogues.

\section{References}

[1] (a) Sinibaldi ME, Canet, I (2008) Eur. J. Org. Chem. 4391-4399; (b) Dake, G (2006) Tetrahedron 62:3467-3492; (c) Galliford CV, Scheidt, KA (2007) Angew. Chem. Int. Ed. 46:8748-8758; (d) Singh, GS, Desta, ZY (2012) Chem. Rev. 112:6104-6155; (e) Fujita S, Nishikawa K, Iwata T, Tomiyama T, Ikenaga H, Mastumoto K, Shindo M (2018) Chem. Eur. J. 24:1539-11543; (f) Altman RA, Nilsson BL, Overman LE, Read de Alaniz J, Rohde JM, Taupin V (2010) J. Org. Chem. 75:7519-7534; (g) Burkhard JA, Wagner B, Fischer H, Schuler F, Müller K, Carreira EM, (2010) Angew. Chem., Int. Ed. 49:3524-3527

[2] Compain P, Martin OR (2007) Iminosugars from synthesis to therapeutic applications. Wiley, Weinheim

[3] Winchester BG (2009) Tetrahedron: Asymm. 20:645-651

[4] Nash RJ, Kato A, Yu CY, Fleet GWJ (2011) Future Med. Chem. 3:1513-1521

[5] Horne G., Wilson FX (2011) Prog. Med. Chem., 50:135-176

[6] Orsato A, Barbagallo E, Costa, B, Olivieri S, De Gioia L, Nicotra F, La Ferla B (2011) Eur. J. Org. Chem. 5012-5019

[7] Decroocq C, Stauffert F, Pamlard O, Oulaïdi F, Gallienne E, Martin OR, Guillou C, Compain P (2015) Bioorg. Med. Chem. Lett. 25:830-833

[8] Santos C, Stauffert F, Ballereau S, Dehoux C, Rodriguez F, Bodlenner A, Compain P, Génisson Y (2017) Bioorg. Med. Chem. 25:1984-1989

[9] Markham A, (2016) Drugs 11:1147-1152

[10] Compain P, Decroocq C, Iehl J, Holler M, Hazelard D, Mena Barragán T, Ortiz Mellet C, Nierengarten JF (2010) Angew. Chem., Int. Ed. 49:5753-5756

[11] Compain P, Bodlenner A (2014) ChemBioChem 15:1239-1251

[12] Gouin S (2014) Chem. Eur. J. 20:11616-11628

[13] (a) Lillelund VH, Jensen HH, Liang X, Bols M (2002) Chem. Rev. 102:515-553; (b) Gloster TM, Davies, GJ (2010) Org. Biomol. Chem. 8:305-320

[14] Zheng Y, Tice CM, Singh SB (2014) Bioorg. Med. Chem. Lett. 24:3673-3682

[15] For a review on conformationally restricted glycoside derivatives see: Maaliki C, Gauthier C, Massinon O, Sagar R, Vincent SP, Blériot Y (2014) in Carbohydrate Chemistry, ed. Pilar Rauter A, Lindhorst T, Queneau Y, Royal Society of Chemistry, Cambridge, 2014, Ch. 20, pp. 418-444

[16] Lahiri R, Ansari AA, Vankar YD (2013) Chem. Soc. Rev. 42:5102-5118 
[17] Yanagisawa H, Kinoshita M, Umezawa S (1971) Bull. Chem. Soc. Jap. 44:3399-3405

[18] (a) Rios R (2012) Chem. Soc. Rev. 41:1060-1074 ; Ding A, Meazza M, Guo H, Yang JW, Rios R (2018) Chem. Soc. Rev. 47:5946-5996.

[19] Kapferer P, Birault V, Poisson JF, Vasella A. (2003) Helv. Chim. Acta 86:2210-2227.

[20] Ahmadian M, Khare NK, Riordan JM, Klon AE, Borhani DW (2001) Tetrahedron 57:9899-9909

[21] Brewster K, Harrison JM, Inch TD, Williams NJ (1987) J. Chem. Soc. Perkin Trans. 1 21-26

[22] Nocquet PA, Hensienne R, Wencel-Delord J, Wimmer E, Hazelard D, Compain P (2015) Org. Biomol. Chem. 13:9176-9180

[23] Nocquet PA, Hensienne R, Wencel-Delord J, Laigre, E, Sidelarbi K, Becq F, Norez C, Hazelard D, Compain P (2016) Org. Biomol. Chem. 14:2780-2796

[24] Nocquet PA, Hazelard D, Gruntz G, Compain P (2013) J. Org. Chem. 78:6751-6757

[25] For a review on square sugars see: Hazelard D, Compain P (2017) Org. Biomol. Chem. 15:3806-3827

[26] Lin W, Gupta A, Kim KH, Mendel D, Miller MJ (2009) Org. Lett. 11:449-452

[27] (a) Haruyama H, Takayama T, Kinoshita T, Kondo M, Nakajima M, Haneishi T (1991) J. Chem. Soc. Perkin Trans. 1 1637-1640; (b) Nakajima M, Itoi K, Takamatsu Y, Kinoshita T, Okazaki T, Kawakubo K, Shindo M, Honma T, Tohjigamori M, Haneishi T (1991) J. Antibiot. 44:293-300; (c) Soengas RG, da Silva G, Estévez JC (2017) Molecules 22:2028

[28] Freire R, Martín A, Pérez-Martín I, Suárez E (2002) Tetrahedron Lett. 43:5113-5116

[29] Martín A, Pérez-Martín I, Suárez E (2009) Tetrahedron 65:6147-6155

[30] Fransisco, CG, Herrera AJ, Martín A, Pérez-Martín I, Suárez E (2007) Tetrahedron Lett. 48:6384-6388

[31] Martín A, Pérez-Martín I, Suárez E (2015) Org. Lett. 7:2027-2030

[32] Pal APJ, Vankar YD (2010) Tetrahedron Lett. 51:2519-2524

[33] Aebisher B, Vasella A (1983) Helv. Chem. Acta 66:789-794

[34] For a review on carbanionic reactivity of the anomeric center in carbohydrates, see: Somsák L (2001) Chem. Rev. 101:81-135

[35] Toumieux S, Compain P, Martin OR (2005) Tetrahedron Lett. 46:4731-4735

[36] Alves RJ, Castillon S, Dessinges A, Herczegh P, Lopez JC, Lukacs G, Olesker A, Thang TT (1988) J. Org. Chem. 53:4616-4618

[37] Tardy S, Vicente JL, Tatibouët A, Dujardin G, Rollin P (2008) Synthesis 3108-3120.

[38] (a) Bourgeois JM (1976) Helv. Chem. Acta 59:2114-2124; (b) Bourgeois JM (1974) Helv. Chem. Acta 57:2553-2557

[39] Bourgeois JM (1975) Helv. Chem. Acta 58:363-372

[40] Sayago FJ, Pradera MÁ, Gasch C, Fuentes J (2006) Tetrahedron 62:915-921

[41] (a) Roy A, Achari B, Mandal SB (2006) Tetrahedron Lett. 47:3875-3879; (b) Maity JK, Ghosh R, Drew MGB, Achari B, Mandal SB (2008) J. Org. Chem. 73:4305-4308

[42] Mascitti V, Robinson RP, Préville C, Thuma, BA, Carr CL, Resse MR, Maguire RJ, Leininger MT, Lowe A, Steppan CM (2010) Tetrahedron Lett. 51:1880-1883

[43] Chincholkbar PM, Puranik VG, Deshmukh ARAS (2007) Tetrahedron 63:9179-9187

[44] Mio S, Kumagawa Y, Sugai S (1991) Tetrahedron 47:2133-2144

[45] Sano H, Mio S, Kitagawa J, Sugai S (1994) Tetrahedron: Asymm. 5:2233-2240

[46] (a) Zhang K, Schweizer F (2005) Synlett 3111-3115; (b) Zhang K, Schweizer F (2009) Carbohydr. Res. 344:576-585

[47] For selected reviews see: (a) Hazelard D, Compain P (2017) Top. Heterocycl. Chem. 47:111-154; (b) Compain P (2007) Adv. Synth. Catal. 349:1829-1846; (c) Felpin FX, Lebreton J (2003) Eur. J. Org. Chem. 3693-371; (d) Dragutan I, Dragutan V, Mitan C, 
Vosloo HCM, Delaude L, Demonceau A (2011) Belstein J. Org. Chem. 699-716; (e) Deiters A, Martin SF (2004) Chem. Rev. 104:2199-2238

[48] Pal APJ, Gupta P, Reddy YS, Vankar YD (2010) Eur. J. Org. Chem. 6957-6966

[49] (a) Robertson J, Stevens K (2017) Nat. Prod. Rep. 34:62-89; (b) Davies SG, Fletcher AM, Roberts PM, Thomson JE (2017) Synlett 2697-2706; (c) Pansare SV, Thorat RG (2013) Targets Heterocycl. Syst. 17:57-86; (d) Kim IS, Jung YH (2011) Heterocycles 83:2489-2507

[50] Rowicki T (2016) Targets Heterocycl. Syst. 20:409-447

[51] (a) Forcher G, Clousier N, Beauseigneur A, Setzer P, Boeda F, Pearson-Long MSM, Karoyan P, Szymoniak J, Bertus P (2015) Synthesis 992-1006 ; (b) Szalata C, Szymoniak J, Fabis F, Butt-Gueule S, Rault S, Bertus P, Gerard S, Sapi J (2013) ChemMedChem 8:70-73; (c) Wolan A, Six Y (2010) Tetrahedron 66:15-61; (d) Bertus P, Szymoniak J, Jeanneau E, Docsa T, Gergely P, Praly JP, Vidal S (2008) Bioorg. Med. Chem. Lett. 18:4774-4778; (e) Bertus P, Szymoniak J (2007) Synlett 1346-1356

[52] Pearson MSM, Plantier-Royon R, Szymoniak J, Bertus P, Behr JB (2007) Synthesis 3589-3594

[53] Pearson MSM, Floquet N, Bello C, Vogel P, Plantier-Royon R, Szymoniak J, Bertus P, Behr JB (2009) Bioorg. Med. Chem. 17:8020-8026

[54] Laroche C, Plantier-Royon R, Szymoniak J, Bertus P, Behr JB (2006) Synlett 223-226

[55] Laroche C, Behr JB, Szymoniak J, Bertus P, Schütz C, Vogel P, Plantier-Royon R (2006) Bioorg. Med. Chem. 14:4047-4054

[56] Dhand V, Draper JA, Moore J, Britton R (2013) Org. Lett. 15:1914-1917

[57] Chen W, Pinto B M (2007) Carbohydr. Res. 342:2163-2172

[58] Morozov DA, Kirilyuk IA, Komarov DA, Goti A, Bagryanskaya IY, Kuratieva NV, Grigor'ev IA (2012) J. Org. Chem. 77:10688-10698

[59] Malik M, Witkowski G, Ceborska M, Jarosz S (2013) Org. Lett. 15:6214-6217

[60] Behr JB, Kalla A, Harakat D, Plantier-Royon R (2008) J. Org. Chem. 73:3612-3615

[61] D’Orazio G, Martorana AM, Filippi G, Polissi A, De Gioia L, La Ferla B (2016) ChemistrySelect 1:2444-2447

[62] (a) Hottin A, Scandolera A, Duca L, Wright DW, Davies GJ, Behr JB (2016) Bioorg. Med. Chem. Lett. 26:1546-1549; (b) Hottin A, Wright DW, Dubar F, Steenackers A, Delannoy P, Biot C, Davies GJ, Behr JB (2013) Chem. Eur. J. 19:9526-9533; (c) Hottin A, Dubar F, Steenackers A, Delannoy P, Biot C, Behr JB (2012) Org. Biomol. Chem. 10:5592-5597; (d) Garcia-Moreno MI, Diaz-Perez P, Ortiz Mellet, C, Garcia Fernandez JM (2002) Chem. Commun. 848-849; (e) Zhou Y, Zhao Y, Boyle KMO, Murphy PV (2008) Bioorg. Med. Chem. 18:954-958

[63] Chavan SR, Gavale KS, Khan A, Joshi R, Kumbhar N, Chakravarty D, Dhavale DD (2017) ACS Omega 2:7203-7218

[64] Chavan SR, Gavale KS, Kamble KM, Pingale SS, Dhavale DD (2017) Tetrahedron 73:365-372

[65] Kui EL, Kanazawa A, Philouze C, Poisson JF, Py S (2017) Eur. J. Org. Chem. 363372

[66] Eum H, Choi J, Cho CG, Ha HJ (2015) Asian J. Org. Chem. 4:1399-1409

[67] Parihar VS, Pawar NJ, Ghosh S, Chopade B, Kumbhar N, Dhavale DD (2015) RSC Adv. 5:52907-52915

[68] Kazmierski WM, Furfine E, Spaltenstein A, Wright LL (2002) Bioorg. Med. Chem. Lett. 12:3431-3433

[69] Duffy RA, Morgan C, Naylor R, Higgins GA, Varty GB, Lachowicz JE, Parker EM (2012) Pharmacol. Biochem. Behav. 102:95-100 